\title{
Uruguay: Financial System Stability Assessment, including Reports on the Observance of Standards and Codes on the following topics: Banking Supervision and Payment Systems
}

This Financial System Stability Assessment on Uruguay was prepared by a staff team of the International Monetary Fund and the World Bank as background documentation for the periodic consultation with the member country. It is based on the information available at the time it was completed on June 9,2006. The views expressed in this document are those of the staff team and do not necessarily reflect the views of the government of Uruguay or the Executive Board of the IMF.

The policy of publication of staff reports and other documents by the IMF allows for the deletion of market-sensitive information.

To assist the IMF in evaluating the publication policy, reader comments are invited and may be sent by e-mail to publicationpolicy@imf.org.

Copies of this report are available to the public from

International Monetary Fund $\bullet$ Publication Services

700 19th Street, N.W. • Washington, D.C. 20431

Telephone: (202) 6237430 • Telefax: (202) 6237201

E-mail: publications@imf.org • Internet: http://www.imf.org

Price: $\$ 18.00$ a copy

\section{International Monetary Fund}

Washington, D.C. 



\title{
INTERNATIONAL MONETARY FUND
}

\section{URUGUAY}

\section{Financial System Stability Assessment}

\section{Prepared by the Monetary and Financial Systems and Western Hemisphere Departments}

\author{
Approved by Ulrich Baumgartner and Anoop Singh
}

June 9, 2006

\begin{abstract}
This Financial System Stability Assessment (FSSA) is based on work undertaken during the Financial Sector Assessment Program (FSAP) for Uruguay, which included visits to Montevideo in October 2005 and January-February 2006. The findings were further discussed with the Uruguayan authorities during the Article IV consultation mission in May 2006. The team was headed by Ceyla Pazarbasioglu (IMF) and was composed of James Hanson (deputy chief, World Bank), Jorge Canales-Kriljenko, Marco Espinosa, Ivan Guerra, Socorro Heysen, Silvia Iorgova, Andrei Kirilenko, André Santos (all IMF), Mariluz Cortes, Gustavo Demarco, Mario Guadamillas, W. Britt Gwinner, John Pollner, Craig Thorburne (all World Bank), Ernesto Livacic and Walter Zunic (consultants). The AML/CFT assessment was carried out by a separate team led by Manuel G. Vasquez. The main findings are as follows:
\end{abstract}

- Over the last three years, the regulation and supervision of the financial system, in particular of the banking sector, have improved significantly. Risk management and internal control systems have been strengthened and the authorities have taken various measures to internalize credit risks from dollarization and cross-border activities. The improved liquidity and capital adequacy of the banking system have increased its capacity to withstand shocks.

- However, macroeconomic and financial risks remain due to the high level of government debt, guarantees to state banks, high dollarization, and the still high share of nonresident deposits.

- The large state presence in the financial system creates distortions and further restructuring of these institutions is needed to minimize the moral hazard problems.

- The key challenge for the authorities is to deepen financial intermediation while reducing vulnerabilities. Required policies and reforms towards this goal include improving the credit culture and credit registry, strengthening bankruptcy procedures, strengthening the governance and performance of the state-owned institutions; reforming the public pension system, which is in deficit; strengthening the banking safety net and supervisory arrangements; developing local capital markets; improving the housing market by better targeting and accounting of subsidies and allowing the private mortgage market to grow; as well as enhancing financial infrastructure.

The main authors of this report are Mmes. Pazarbasioglu and Heysen, with contributions from other team members.

FSAPs are designed to assess the stability of the financial system as a whole and not that of individual institutions. They have been developed to help countries identify and remedy weaknesses in their financial sector structure, thereby enhancing their resilience to macroeconomic shocks and cross-border contagion. FSAPs do not cover risks that are specific to individual institutions such as asset quality, operational or legal risks, or fraud. 
Contents

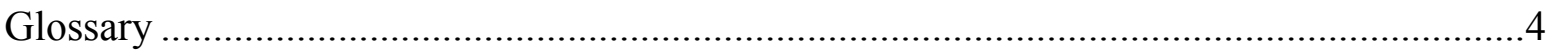

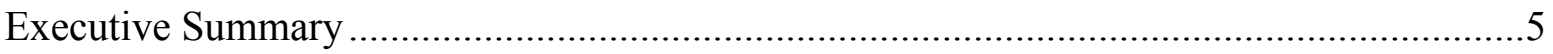

I. Financial Structure and Macroeconomic Environment .................................................

A. Overview of the Financial System .....................................................................

B. Macroeconomic Environment After the Crisis ......................................................13

II. Macro-Financial Stability Analysis .......................................................................

III. Strengths and Challenges of the Financial System ................................................16

A. Commercial Banks......................................................................................16

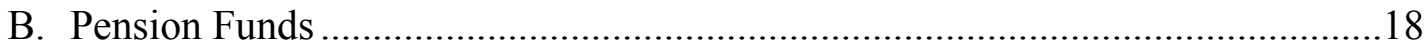

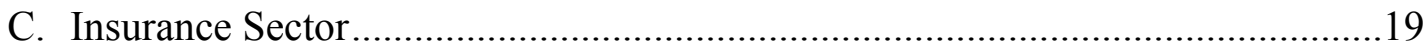

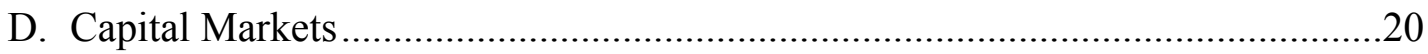

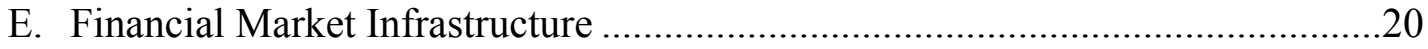

IV. The Financial Stability Policy Framework …………….............................................22

A. Independence of Central Bank and Regulatory Institutions ...............................21

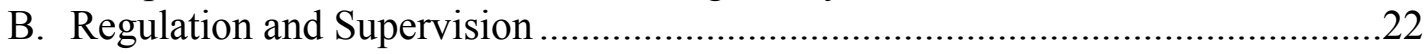

Annex

Reports on Observance of Financial Sector Standards and Codes ......................................25

Basel Core Principles For Effective Banking Supervision ................................................25

CPSS Core Principles for Systemically Important Payment Systems ...............................31

Tables

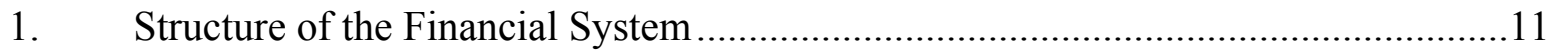

2. Recommended Action Plan to Improve Compliance with the Basel Core Principles...............................................................................30

3. Systemically Important Payments in Uruguay, end-2004 .........................................34

4. Recommended Actions to Improve Observance of CPSS Core Principles .............35

5. Interest Rate Shocks Applied to the U.S. Dollar, Peso, and

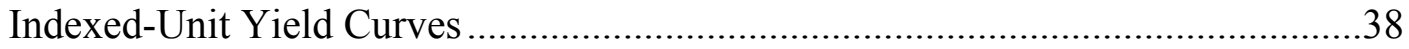

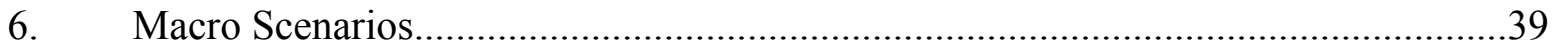

7. Inputs for the Stress Tests under a Domestic Supply Shock (Scenario 1), a Current Account Shock (Scenario 2), and a Capital Account Shock (Scenario 3)...40

8. Banking System Asset and Liability Structure, 2000-05 ……................................42

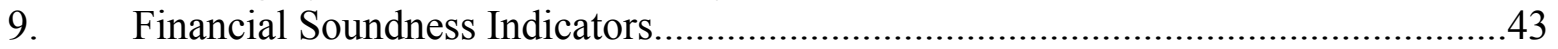

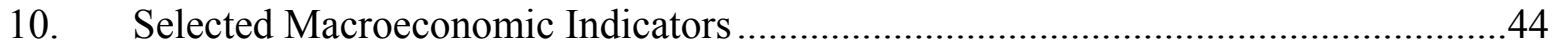

11. Financial Integration and Net Foreign Assets: 2001-04........................................45

12. Regulations that Discriminate by Currency Composition .........................................46 
13. Share of Foreign Currency Credit to the Nontradable Sector in Total Credit .47

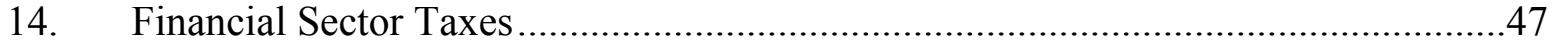

15. Liabilities of Nonfinancial Corporate Sector Denominated or Indexed to Foreign Currency ......................................................................................48

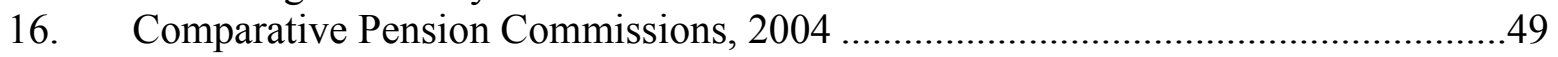

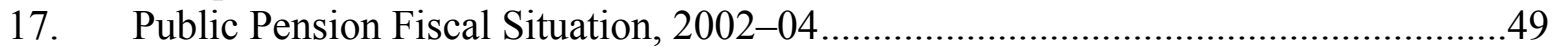

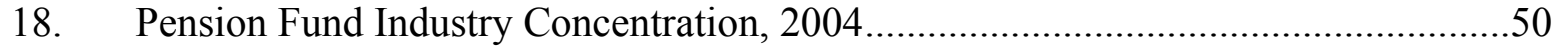

19. Composition of Invested Pension Funds..............................................................50

20. Insurance Sector: Some Comparative Statistics, 2003 ........................................51

21. Chronology of Changes in Selected Prudential Regulations, 2002-05 ...................52

Figures

1. Banking System Assets and Deposits in Latin America, 2004...............................10

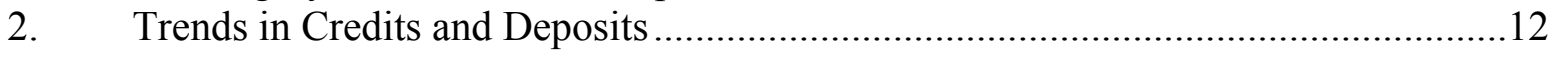

Boxes

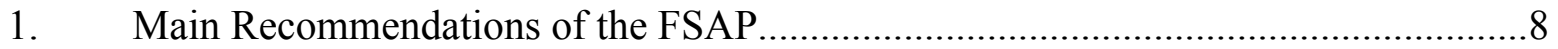

2. Stress Testing the Banking System..................................................................15

3. Measures Taken to Address Liquidity, Market, and Credit Risks ...........................23

Appendices

I. Methodological Aspects of Stress Testing in the Uruguay FSAP ..........................37

II. Summary of Key Recommendations to Strengthen the AML/CFT Regime .............41

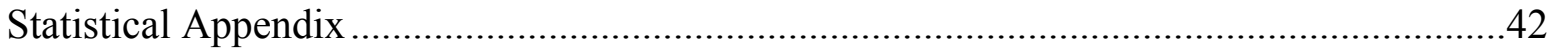




\section{GLOSSARY}

$\mathrm{ACH}$

AFP

AFAP

AML

AMV

BCP

BCU

BEVSA

BHU

BROU

BPS

BSE

BVM

CA

CD

CFT

COPAB

COFIS

CPSIPS

CPSS

DvP

FATF

GAFISUD

IAS

IASB

IFRS

IOSCO

MI

$\mathrm{MoEF}$

$\mathrm{MoH}$

$\mathrm{MoU}$

NBC

OTC

PD

PvP

ROSC

RTGS

SEDEC

SIIF

SOEs

SPAB

SRO

VAT
Automated clearinghouse

Administradoras de Fondos de Pensiones

Administradora de Fondos de Pensión

Anti-money laundering

Área Mercado de Valores y Control de AFAP

Basel Core Principles for Effective Banking Supervision

Banco Central de Uruguay

Bolsa Electrónica de Valores del Uruguay

Banco Hipotecario de Uruguay

Banco de la República Oriental del Uruguay

Banco de Previsión Social

Banco de Seguros del Estado

Bolsa de Valores del Montevideo

Credit administrators

Certificates of deposit

Combating the financing of terrorism

Corporación de Protección del Ahorro Bancario

Contribución Financiamiento Seguridad Social

Core Principles for Systemically Important Payment Systems

Committee on Payment and Settlement Systems

Delivery versus payment

Financial Action Task Force

Grupo de Acción Financiera de Sudamérica

International Accounting Standards

International Accounting Standards Board

International Financial Reporting Standards

International Organization of Securities Commission

Mortgage default insurance

Ministry of Economy and Finance

Ministry of Housing

Memorandum of Understanding

Nuevo Banco Comercial

Over-the-counter

Probability of default

Payment versus payments

Report on Observance of Standards and Codes

Real-Time Gross Settlement

Sistema Electrónico de Comunicaciones

Superintendencia de Instituciones de Intermediación Financiera

State-owned enterprises

Superintendencia de Protección del Ahorro Bancario

Self-regulatory organization

Value-added tax 


\section{EXECUTIVE SUMMARY}

Improved liquidity and capital adequacy have increased the Uruguayan banking system's capacity to withstand shocks. However, macroeconomic and financial risks remain due to the high level of government debt, guarantees to state banks, high dollarization, and a high share of nonresident deposits. Two years after the crisis, depositors continue to utilize mostly sight deposits perhaps reflecting that the confidence in the system has not yet been fully restored. The regulation and supervision of the financial system have improved significantly and the authorities have taken measures to internalize credit risks from dollarization and cross-border activities. The challenge for the authorities is to deepen financial intermediation while continuing to reduce vulnerabilities.

The financial sector is recovering from the $\mathbf{2 0 0 2}$ crisis. The banking system is well capitalized and liquid, partly reflecting the sharp reduction in lending. Bank assets have halved in dollar terms to about US $\$ 12$ billion at end-2005, of which 36 percent are held in liquid assets; loans to the private sector were 26 percent of GDP. Nonresident deposits now account for 20 percent of total deposits, down from 50 percent in 2001, and dollarization is gradually falling but remains higher than before the crisis. The defined-contribution pension system has weathered the crisis well and is growing while the insurance sector remains small and capital markets are in their infancy.

The crisis highlighted the key underlying weaknesses of the Uruguayan financial sector. These weaknesses included:

- $\quad$ High dollarization and a large share of nonresident deposits;

- Inadequate oversight, governance, internal controls, and risk management systems in state financial institutions and some private institutions;

- $\quad$ The failure of prudential regulations and policies to reduce credit and liquidity risks arising from high financial dollarization and cross-border activities;

- Government policies on, and lack of effective supervision of, state banks, which gave rise to large uncovered foreign currency liabilities, nonperforming loans, and contingent liabilities; and,

- $\quad$ An inadequate bank resolution framework for private banks and difficulties in resolving the problems of the state banks, both of which were complicated by rigid employment practices.

Over the last three years, the regulation and supervision of the financial system, in particular of the banking sector, have improved significantly. Risk management and internal control systems have been strengthened across financial institutions. The deposit insurance fund became operational in 2005. The largest state bank, BROU, has made improvements in disclosure, risk management and internal controls, but remains subject to high liquidity and reserve requirements pending further improvements to its risk 
management, loan approval and recovery processes. BROU lacks adequate procedures to measure and price risks and despite improvements, information systems are not yet up to standards for a bank that size. The state housing bank, BHU, was prohibited from accepting new deposits by modifications in its charter after its deposits were transferred to BROU, and additional restructuring is envisaged in the near future. Three key problems common to all sectors hinder the effectiveness of financial sector oversight - lack of resources, limits on powers with regard to state institutions, and quality of data that state institutions provide. Amendments to the central bank law that will strengthen BCU autonomy were submitted to congress and were expected to be debated later in 2006.

The authorities have taken measures to internalize credit risks from dollarization and cross-border activities. BCU has introduced a series of prudential limits to reduce exposures and concentration of risks, especially regarding dollarization, and has increased liquidity requirements on non resident deposits. In addition to these measures, the authorities may consider issuing more index-linked debt to promote de-dollarization and conducting an analysis of costs and benefits of further restricting onshore banks capacity to attract nonresident deposits (for example by imposing higher liquidity requirements) in view of the potential volatility of these deposits. The BCU has systematically increased the disclosure of financial information, which has contributed to greater market discipline.

\section{However, macroeconomic and financial risks remain due to the high level of government debt, guarantees to state banks, high dollarization, and the still high share of nonresident deposits. Improved capital adequacy have increased the banking system's capacity to withstand shocks. The improved liquidity position of public banks has reduced the need for public support in the event of a moderate liquidity shock. However, in the event of major shocks, liquidity problems might be exacerbated as the provision of emergency liquidity assistance in foreign currency is constrained by the amount of international reserves and access to international capital markets. Strong macroeconomic policies and reforms of state financial institutions, as discussed below, are critical to increasing the resiliency of the financial system.}

The large state presence in the financial system creates distortions. BROU alone accounts for over 40 percent of bank assets and 50 percent of deposits, which are fully guaranteed by the state. BROU owns majority stake in the largest pension fund, which accounts for over half of total pension fund assets and guarantees a minimum return. The state-owned insurance company accounts for over 60 percent of the insurance market and by offering low-cost life insurance to AFAP affiliates, has driven out private competitors. The predominance of state-owned institutions throughout the financial sector raises informational, oversight, and governance issues, making regulation and supervision challenging. Moreover, government guarantees to state-owned institutions and practices of these institutions limit financial development and the ability of private institutions to compete on a level playing field.

Continued restructuring of the state institutions is needed to maintain stability and minimize moral hazard. Given the strong views of the Uruguayan society against 
privatization, the staff recommended that the authorities restructure and downsize public financial institutions and consider a limited public offering by these institutions. Such private ownership with proportional representation on the board, even with a minority stake, may promote greater transparency and market discipline. State banks should be restricted in deposit and lending activities and charge rates comparable to that of private banks. It is critical that the authorities continue to refrain from political interference in state banks' lending and loan collection efforts, including loan recovery in the liquidation funds, in order to transform an environment that has in the past favored a culture of nonpayment of debts into one in which there are incentives to build a good credit history.

Banks' efforts to reduce intermediation costs are constrained by high reserve and liquidity requirements, distortionary taxes, and labor market rigidities. While liquidity risks associated with high foreign currency deposits justifies relatively high reserve requirements, the low rate paid by the central bank on these reserves has effectively become an additional tax. Financial intermediaries are subject to various taxes; the tax reform submitted to congress in March 2006 should lead to a significant reduction in the tax burden of the financial system. Rigidities in labor markets make it difficult to reduce labor costs and strikes by employees at times have delayed restructuring efforts in intervened banks.

The Uruguayan pension system weathered the crisis quite well, but it needs reform to reduce projected fiscal costs and potential contingent liabilities. The public pension system's deficit, after earmarked taxes, amounted to 2.6 percent of GDP as of end-2004 reflecting the aging of the population and exemptions of some employers from contributions. Some sectoral pension schemes may represent a potential risk to the government, notably the financially weak scheme for bank employees (Caja Bancaria). The authorities are considering reforms to address these issues. Investment regulations governing the AFAPs need to be amended to ensure a prudent asset diversification of affiliates' investments.

There is a need to improve the data quality, price policies, and internal risk management and control systems of the state-owned BSE, which dominates the insurance sector. The insurance companies need to improve capital and risk management practices, and oversight of the sector needs to be strengthened. The lack of reinsurance of worker's compensation and life insurance policies creates a contingent fiscal risk.

The development of local capital markets would benefit from improvements in corporate governance and disclosure practices. A new draft law on capital markets is expected to improve the legal framework and the proposed new tax law envisages major simplifications in taxation that would make securitization easier. The draft amendments includes corporate governance provisions that are in accordance with IOSCO standards.

The key challenge for the authorities is to deepen financial intermediation while reducing vulnerabilities. Required policies and reforms towards this goal include improving the credit culture, strengthening the governance and performance of the state-owned financial institutions, reforming the public pension system, strengthening financial sector supervision, and developing local capital markets (Box 1 provides detailed recommendations). 


\section{Box 1. Main Recommendations of the FSAP}

\section{Key short-term stability-related issues}

- $\quad$ Continue close monitoring of public banks to ensure that their risk management policies and practices are brought up to standard.

- $\quad$ Continue to limit lending activities in these banks until such improvements are achieved.

\section{Key structural and longer-term issues}

- $\quad$ Restructuring and downsizing of the state institutions, in particular state banks, to minimize moral hazard.

- $\quad$ Require directors and managers of public financial institutions to satisfy fit and proper requirements applied to private institutions.

- $\quad$ Strengthen central bank independence and recapitalize the central bank as envisaged in the draft law submitted to congress.

- $\quad$ Remove the selective employer exemptions from contributions to public pensions as envisaged in the proposed tax law, carry out further reforms to reduce the public and sectoral pension funds' deficits, and eliminate the government-guaranteed minimum rate of return in AFAP República.

- $\quad$ Conduct an independent analysis of the potential contingent liabilities from products offered by the state insurance company, BSE, as well as any proposals for mortgage insurance.

- $\quad$ Reform insolvency legislation to allow for the reorganization of viable firms and the faster, efficient liquidation of nonviable ones as envisaged in the proposed bankruptcy law.

- Improve corporate governance and disclosure practices in the context of measures to develop local capital markets.

- Implement the shift to an upgraded RTGS system and improve the legal framework related to payment and securities settlement systems.

\section{Strengthening the supervisory and regulatory framework}

- Increase resources to carry out effective supervision and to provide training for staff; improve information systems.

- $\quad$ Provide legal protection for staff of supervisory agencies and deposit insurance agency.

- $\quad$ Enhance AML/CFT legislation.

- Improve cooperation and information exchange with foreign supervisors, including through additional MOUs.

- $\quad$ Reduce the tax burden and improve the legal and regulatory framework for trust funds and securitizations.

- $\quad$ Enhance the regulatory authority over securities intermediaries. 


\section{FinAnCial StruCture AND MACROECONOMIC ENVIRONMENT}

1. Uruguay suffered a severe banking crisis in 2002. The withdrawal of nonresident deposits - accounting for over 50 percent of total deposits at end-2001-due to the crisis in Argentina triggered a general run on deposits in Uruguayan banks. Liquidity pressures and the sharp increase in nonperforming loans after the devaluation as well as corporate governance problems set off a series of bank failures. Four insolvent private banks were closed and some large depositors lost part of their savings. The state banks' already large nonperforming loans increased sharply and these banks' time deposits had to be reprogrammed and their assets substantially restructured. The initial fiscal cost of resolving the banking crisis is estimated at about 20 percent of 2002 GDP; the final outcome will depend on asset recovery. The insurance sector also suffered, but the pension system weathered the crisis relatively well. Many corporates experienced severe losses due to their high levels of dollar-denominated debt.

\section{A. Overview of the Financial System}

2. The Uruguayan financial system is dominated by banks. The banking sector, accounts for 67 percent of total assets (78 percent of GDP) at end-2005 and is relatively large by regional standards (Figure 1 and Table 1). The defined-contribution pension system (assets of 11 percent of GDP) has grown since the crisis while the insurance sector remains very small (assets of 3 percent of GDP). The other nonbank financial intermediaries consist of cooperatives and finance houses that together have assets of about 2 percent of GDP. Offshore banking assets account for 17 percent of GDP, a result of Uruguay's role as a regional offshore center. The equity market (capitalization of 2.2 percent of GDP) and the domestic corporate bond market (outstanding amount of 0.5 percent of GDP) are small and illiquid by regional standards. The domestic public debt (about 16 percent of GDP, of which about 70 percent is denominated in foreign currency) is mostly concentrated in short-term instruments, while external public debt (about 57 percent of GDP and denominated in foreign currency) is mainly held by foreign investors.

\section{State institutions account for more than half of the financial sector and foreign} institutions account for most of the rest. The public commercial bank, Banco de la República Oriental del Uruguay (BROU), accounts for 41 percent of banking system assets. The public mortgage bank, Banco Hipotecario de Uruguay (BHU), which accounts for another 11 percent, has been constrained from taking new deposits and is focusing on recovery of its nonperforming assets, estimated at nearly 70 percent of the portfolio. The number of private banks has declined from 21 to 12 in the aftermath of the 2002 crisis and only foreign-owned banks remain. The largest pension fund, which accounts for about 57 percent of pension assets, is state-owned while the state-owned insurance company, formerly a monopoly, has over two thirds of the insurance business. 
Figure 1. Banking System Assets and Deposits in Latin America, 2004 (In percent of GDP)

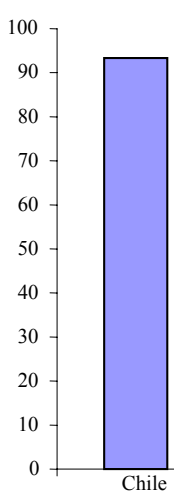

Total Assets
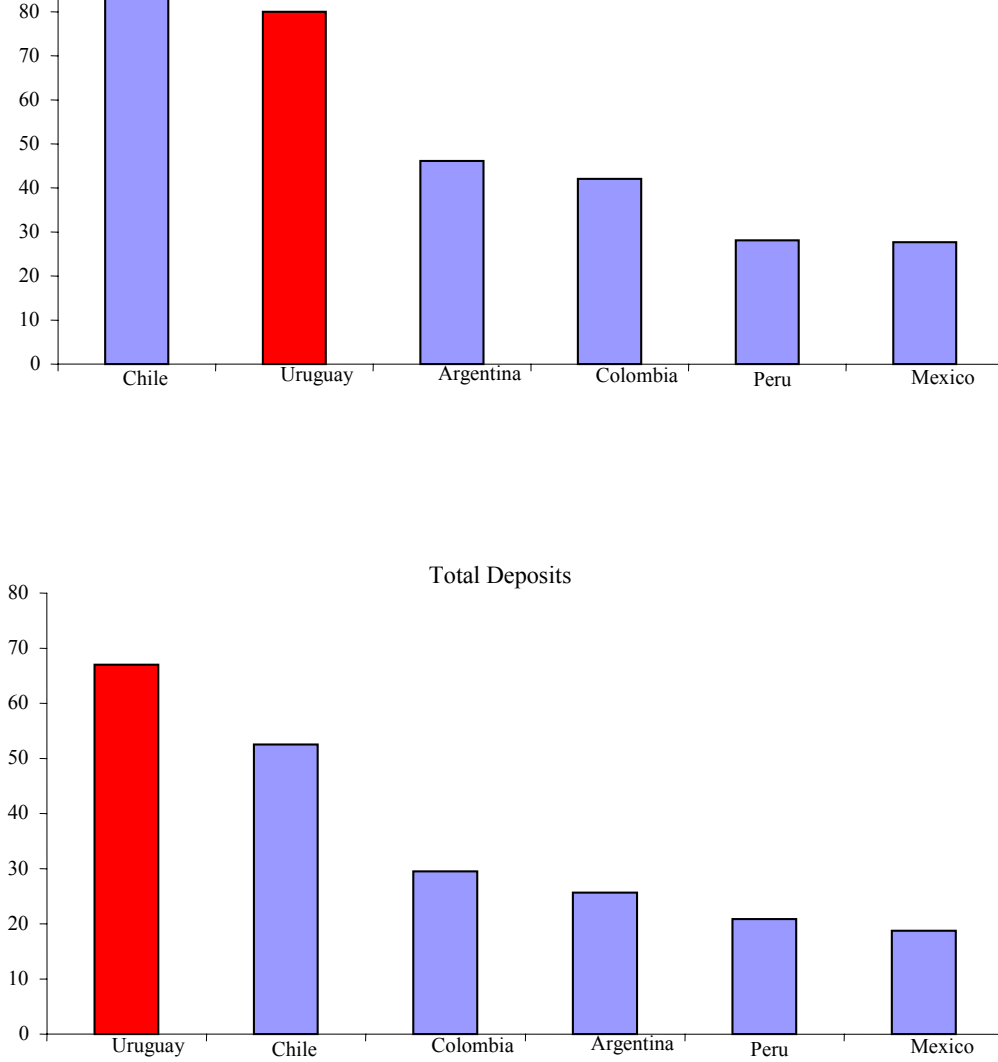

Note: Data for Uruguay is as of December 2005.

Sources: IMF staff calculations based on data from Uruguayan authorities, Superintendencia de Bancos e Instituciones Financieras-Chile, Federación Latinoamericana de Bancos, IMF International Financial Statistics and WEO. 
Table 1. Uruguay: Structure of the Financial System

\begin{tabular}{|c|c|c|c|c|c|c|}
\hline & \multicolumn{3}{|c|}{ December 31, 2001} & \multicolumn{3}{|c|}{ December 31,2005} \\
\hline & Number & $\begin{array}{c}\text { Assets } \\
\text { (In millions } \\
\text { of U.S. } \\
\text { dollars) }\end{array}$ & $\begin{array}{l}\text { Percent of } \\
\text { Total Assets }\end{array}$ & Number & $\begin{array}{c}\text { Assets } \\
\text { (In millions } \\
\text { of U.S. } \\
\text { dollars) }\end{array}$ & $\begin{array}{l}\text { Percent of } \\
\text { Total Assets }\end{array}$ \\
\hline $\begin{array}{l}\text { Commercial Banks } \\
\text { Of which }\end{array}$ & 22 & 20,609 & 82 & 15 & 12,951 & 67 \\
\hline Public sector-owned banks & 2 & 7,457 & 30 & 3 & 7,885 & 41 \\
\hline BROU & 1 & 4,788 & 19 & 1 & 5,540 & 29 \\
\hline BHU & 1 & 2,668 & 11 & 1 & 1,318 & 7 \\
\hline Nuevo Banco Comercial S.A. & & & & 1 & 1,027 & 5 \\
\hline Domestic private banks & 3 & 3,172 & 12 & 0 & 0 & 0 \\
\hline Foreign banks $1 /$ & 17 & 9,980 & 40 & 12 & 5,066 & 26 \\
\hline Nonbank intermediaries & 25 & 2,834 & 12 & 15 & 3,546 & 19 \\
\hline Cooperatives & 6 & 478 & 2 & 3 & 211 & 1 \\
\hline Financial houses & 7 & 540 & 2 & 6 & 157 & 1 \\
\hline External financial institutions 2/ & 12 & 1,816 & 8 & 6 & 3,178 & 17 \\
\hline Pension funds (AFPs) & 4 & 1,045 & 4 & 4 & 2,164 & 11 \\
\hline Insurance companies & 17 & 572 & 2 & 15 & 619 & 3 \\
\hline Total financial system & 68 & 25,060 & 100 & 49 & 19,280 & 100 \\
\hline
\end{tabular}

Source: Banco Central de Uruguay.

$1 /$ Includes both foreign branches and subsidiaries.

$2 /$ Includes derivatives transactions.

4. The banking system is recovering from the $\mathbf{2 0 0 2}$ crisis but it still faces important challenges. The banking system has become smaller and more liquid, with a corresponding reduction in the lending portfolio, and is adequately capitalized (Statistical Appendix, Tables 8 and 9). Banks returned to profitability in 2005 following a recovery in collection rates as the economy rebounded. The system nonetheless faces challenges to increase lending and further improve asset quality despite the lack of credit demand from qualified corporate borrowers. Asset quality has improved but remains an issue for state banks while private banks largely wrote off their nonperforming loans.

\section{The banking sector is highly dollarized and nonresident deposits account for a} significant share of total deposits. The share of dollar deposits and credits rose sharply in 2002 following a large depreciation of the peso. The dollarization process has been gradually reversed as confidence in the peso strengthened, capital returned to Uruguay, and the peso appreciated. However, the system remains highly dollarized. By end 2005, foreign currency deposits amounted to 85 percent of total nonfinancial resident deposits and credit denominated in foreign currency to 71 percent of total credit (Figure 2). The deposits of nonresidents account for about 23 percent of total nonfinancial sector deposits, a ratio which has declined from over 50 percent at end-2001. Two years after the crisis, depositors continue to utilize mostly sight deposits perhaps reflecting that the confidence in the system has not yet been fully restored. 
Figure 2. Uruguay: Trends in Credits and Deposits
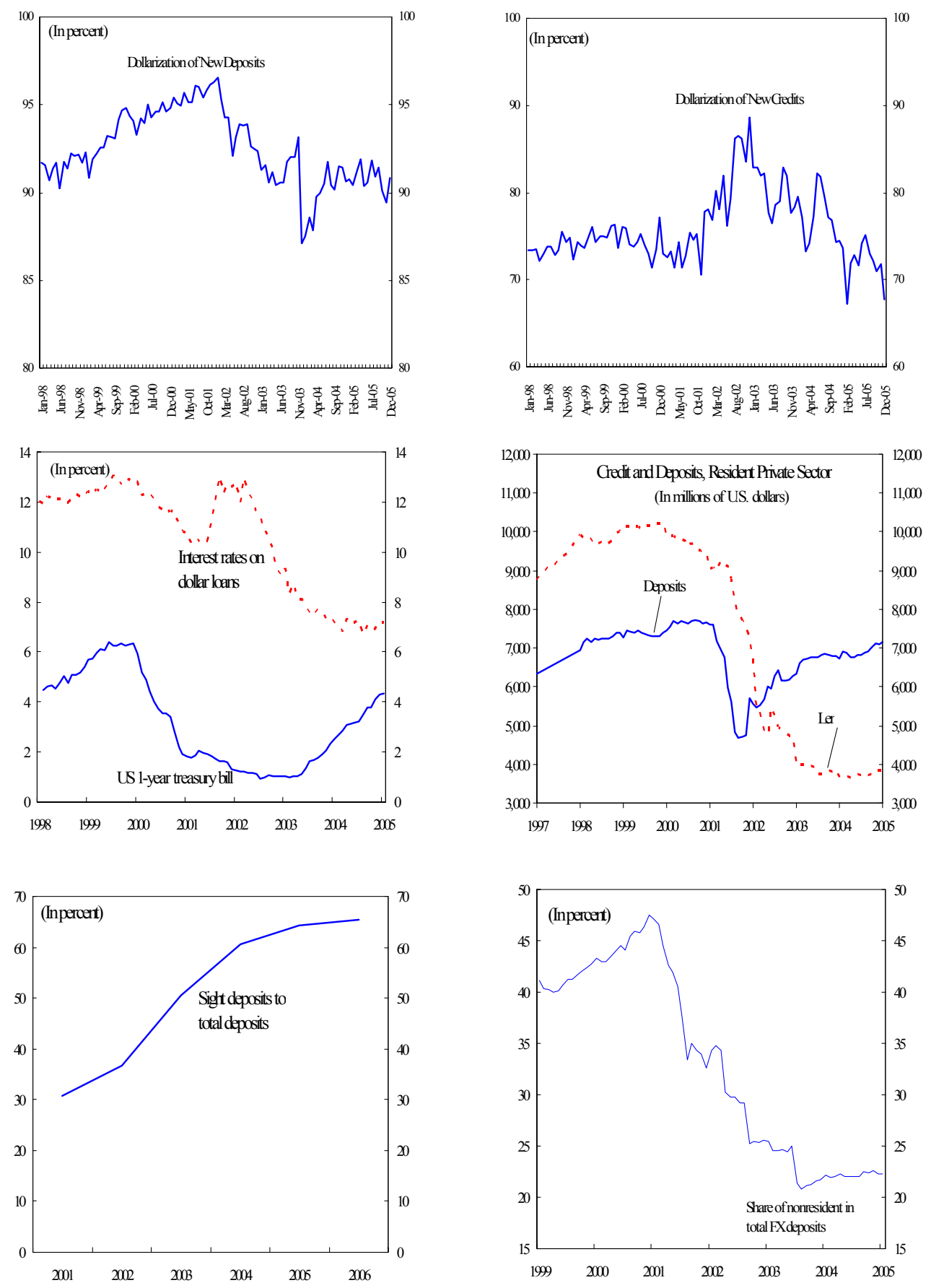

Sources: BC; and IMF staffestinates. 
6. The insurance sector also suffered from the crisis while the pension system weathered it relatively well. Life insurance policy holders cashed out their policies and the sector is only now returning to its 2001 size, as measured in dollars. In contrast, the definedcontribution pension system has grown as contributions continued during the crisis. While the insurance and pension institutions did suffer capital losses on their government debt holdings during the crisis, these losses have been more than offset by capital gains from the fall in interest rates on public debt.

\section{B. Macroeconomic Environment After the Crisis}

7. The authorities implemented a stabilization program following the $\mathbf{2 0 0 2}$ crisis. ${ }^{1}$ Economic activity started to recover in 2003 and sharply accelerated in 2004, growing by 12.3 percent, partly reflecting robust international growth (Statistical Appendix, Table 10). GDP rose by over 6.5 percent in 2005, reaching its 1998 levels in real peso terms. Inflation declined to 4.9 percent by end-2005, from 26 percent at end-2002. The peso has appreciated in real effective terms since August 2004, but by end-2005 it remained about 17 percent more depreciated than in 1998. Export growth has been buoyant, although the current account deficit has widened, partly reflecting higher foreign direct investment.

8. Uruguay's public debt outlook has improved significantly. The public sector debt-to-GDP ratio has fallen from over 105 percent of GDP in 2002 to 69 percent at end-2005. This partly reflects primary surpluses exceeding 3.5 percent of GDP since 2003 as well as the real effective appreciation of the peso, high growth and relatively low international interest rates. Peso interest rates are at their lowest levels in the last 10 years reflecting low international rates, improved inflation expectations, continued peso appreciation, and excess liquidity in the banking system.

9. While the economy is performing well, macroeconomic vulnerabilities remain high. Financial liabilities in both the private and public sectors are largely expressed in foreign currency, while the dollar value of domestic income is exposed to significant volatility. In addition, public debt remains very high and the government's ability to service it depends on continued fiscal discipline, moderate world interest rates, a relatively stable exchange rate, low sovereign risk premia, sustained economic growth, and a proactive debt management strategy. The government also carries contingent liabilities arising from the state banks as well as from the large public pension and insurance sectors.

\section{Macro-Financial Stability Analysis}

10. The main vulnerability in Uruguay is in the interplay between the high level of government debt, state guarantees to public banks, and high dollarization. The state as the owner of BROU offers a full guarantee on deposits, of which 87 percent are in dollars

\footnotetext{
${ }^{1}$ A Fund-supported program accompanied the first three years of stabilization and a three-year stand-by arrangement was approved in June 2005.
} 
(same as prior to the 2002 crisis). In order to fulfill this guarantee and act as the lender of last resort during the 2002 crisis, the government resorted to borrowing bilaterally and from multilateral institutions. ${ }^{2}$ As a result of this, together with the depreciation of the peso, the level of public debt rose from 47 percent of GDP in 2001 to over 105 percent of GDP in 2002 (with most of it denominated in U.S. dollars). In addition, the government accumulated contingent liabilities in the form of a government guarantee on promissory notes to BROU, arising from the transfer of deposits from BHU to BROU and nonperforming loans from BROU to trust funds.

11. While the improved liquidity and capital adequacy of the banking system has increased its capacity to withstand shocks, constraints on the government's ability to act as a lender of last resort could amplify the effects of an external shock on the banking system. According to stress tests, an external shock such as major economic distress in Argentina or a sharp rise in foreign interest rates would lead to a deterioration of the capital adequacy of several financial institutions (Box 2 and Appendix I). The liquidity position of public banks has improved considerably, thus reducing the need for public support in the event of a moderate liquidity shock. However, a major macroeconomic shock (if the government were to lose market access or face sharp adverse movements in exchange rates or interest rates; sudden-stop scenario) may trigger liquidity problems as the provision of liquidity assistance in foreign currency is constrained by the amount of international reserves and access to international capital markets. Strong macroeconomic policies and reforms of state financial institutions are therefore critical to increasing the resiliency of the financial system.

\section{Uruguay is subject to cross-border risks that need to be carefully managed.}

Uruguay is one of the most financially integrated emerging markets (measured by the sum of external assets and liabilities over GDP), but large gross international transactions actually reflect the large off-shore activity (Statistical Appendix, Table 11). This partly reflects the highly liberalized capital account environment which also gives rise to a series of crossborder risks that need to be carefully managed.

\section{The authorities should assess whether higher liquidity requirements on} nonresident deposits are warranted to enhance financial stability. In response to the experience of the 2002 crisis, the authorities raised liquidity requirements to 30 percent of nonresident deposits in 2003. The authorities should assess whether a further increase is appropriate based on the higher liquidity risk from these deposits as well as the cost this would impose on financial institutions.

\footnotetext{
${ }^{2}$ Foreign institutions did not receive lender-of-last-resort support from the central bank and were supported by their parent company.
} 


\section{Box 2. Stress Testing the Banking System}

Stress tests were conducted individually on all private banks, cooperative banks, and BROU.

Bank solvency was tested against movements in exchange and interest rates and a deterioration in credit quality in isolation and in response to adverse macroeconomic events. The macroeconomic scenarios included a domestic supply shock (severe weather conditions), a current account shock (a drop in Argentine GDP of 10 percent), and a capital account shock (sudden stop scenario; major capital outflows leading to a severe recession). The macro scenarios are explained in detail in Appendix I. The estimated capital adequacy ratios (CAR) of banks were compared against the minimum capital requirement ratio (10 percent for banks, finance houses, and offshore banks, and 15 percent for cooperatives).

The results are as follows:

Sensitivity tests: Scenarios incorporating a parallel shift or a tilt in the U.S. dollar and peso yield curves (ranging between 30-100 and 90-160 basis points, respectively) and a 30 percent depreciation or appreciation of the exchange rate, without credit risk considerations, did not lead to a decline in the banks' CAR below the minimum capital requirement ratio. For a very sharp tilt in the U.S. dollar and peso yield curves to a level similar to the one during the Russian crisis (ranging between 163-881 and 123-861 basis points, respectively), the CAR would fall below the minimum capital requirement ratio in financial institutions accounting for about 17 percent of banking system assets (Appendix I, Table 5). Under a stress test of credit risk in which the worst classification for each debtor is applied to that debtor in all banks, the provisioning needs of banks would increase. Finally, an increase of 60 percent in the probability of default would lead to the decline of the capital adequacy ratios of institutions (accounting for about 13 percent of the banking system assets) to below the required minimum.

Adverse macroeconomic events: The stress tests combine the direct effects of exchange and interest rate changes on bank books with the deterioration in the loan portfolio arising from the evolution of macro variables. The domestic supply shock scenario would lead to a decline in the CAR below the minimum required in institutions representing six percent of the banking system. Under the current account shock of a 10-percent decline in Argentina's GDP, financial institutions, representing 28 percent of banking system assets, would become undercapitalized. Finally, under the sudden stop scenario (a severe monetary tightening in the US leading to a recession in the world economy, large capital outflows, and a sudden drop of 8 percent in Uruguayan GDP) banks representing about 80 percent of the banking system assets would have a CAR below the minimum required.

Deposit withdrawals: Bank liquidity was also tested under the same scenarios. Several financial institutions would experience a decline in the 30 and 90-day liquidity ratios below 50 percent under the current and capital account shock scenarios. 


\section{Strengths And Challenges of The Financial System}

\section{A. Commercial Banks}

\section{Distortions created by state banks}

14. Despite recent improvements, state and private banks do not compete on a level playing field. Deposits in state banks have an explicit full government guarantee due to their constitutionally based separate charters. The presidents of the two state banks are nominated by Uruguay's president and approved by parliament, and can only be removed by parliament. Managers and directors of state banks do not go through the same fit and proper filter as those of the private sector, and the superintendency does not have the power to have them removed.

\section{State bank lending has often been politically motivated and fostered a poor credit culture. Public banks have a history of distorting market prices under political pressures to provide sectoral subsidies (on a few occasions, the congress approved a moratorium on agricultural loans). Furthermore, lax credit evaluation procedures and continued refinancing of nonperforming loans by state-owned banks contributed to a sharp increase in nonperforming loans. Public banks have underpriced credit risks and failed to enforce lending obligations in some business segments, such as housing and agricultural loans, to such an extent that private banks have been reluctant to engage in such lending.}

\section{Continued restructuring of state-owned banks is needed to minimize moral}

hazard. The predominance of state-owned institutions throughout the financial sector raises informational, oversight, and governance issues, making regulation and supervision challenging. The restructuring and downsizing of the state institutions, in particular state banks, is needed to maintain stability and minimize moral hazard. Supervisory restrictions imposed on these banks have prevented new unsound lending and have induced some improvements in the credit information of state-owned banks. Given the strong views of the Uruguayan society against privatization, the staff recommended that the authorities restructure and downsize public financial institutions and consider a limited public offering by these institutions. Such private ownership with proportional representation on the board, even with a minority stake, may promote greater transparency and market discipline. State banks should be restricted in deposit and lending activities in charging rates comparable to that of private banks. It is critical that the authorities continue to refrain from political interference in state banks' lending and loan collection efforts, including loan recovery in the liquidation funds, in order to transform an environment that has in the past favored a culture of nonpayment of debts into one in which there are incentives to build a good credit history.

\section{Risk management}

17. Risk management has generally improved, but progress has been uneven. Credit risk standards were tightened in the aftermath of the crisis, and regulation and supervision 
were also refocused to address the risks of a dollarized financial system. The central bank credit registry has been improved in recent years and provides essential and timely information for the evaluation of credit risks by banks and supervisors. Most banks have implemented independent risk management structures and involve senior management in the development of a risk culture. However, the public banks still lack adequate systems to assess their risks (such as daily marking to market, use of VARs, backtesting and internal rating systems).

18. Managing the risks of dollarization is still a challenge and involves many tradeoffs. Traditionally, most banks would lend in foreign exchange to unhedged borrowers which exposes them to significant credit risk. After the crisis, banks have been allocating significant capital as a buffer against this risk and concentrating lending in dollars to the export sector. Furthermore, the BCU has introduced a series of prudential limits to reduce exposures and concentration of risks due to dollarization (Statistical Appendix, Table 12). As a result, the share in total credit of foreign currency loans to the nontradable sector has fallen from 46 to 31 percent between 2003 and 2005 (Statistical Appendix, Table 13).

\section{Costs of financial intermediation and labor market rigidities}

19. Banks' efforts to reduce intermediation costs are constrained by three key obstacles: high reserve and liquidity requirements, distortionary taxes, and labor market rigidities. Liquidity and reserve requirements affect banks' profits adversely. BCU imposes differential reserve requirements depending on the currency composition of deposits (averaging 15 percent on peso deposits and 24 percent on foreign currency deposits). While liquidity risks associated with high foreign currency deposits may justify relatively high reserve requirements, the low rate paid by the central bank on these reserves has effectively become an additional tax. In addition to the usual profit and net worth taxes, Uruguayan financial intermediaries are subject to an asset tax and a tax on the credit portfolio (Statistical Appendix, Table 14). The tax reform submitted to congress in March 2006 envisages elimination of some of these taxes and should lead to a significant reduction in the tax burden of the financial system.

20. Rigidities in labor markets make it difficult to reduce labor costs. Banking sector workers enjoy generous benefits that limit banks' capacity to control costs. Under the system of "bolsas de trabajo," banks are expected to hire the workers of liquidated banks. Benefits paid to dismissed staff are high in the banking sector (payment of up to 20 months salaries in the banking sector versus a maximum of 6 months salaries in other sectors). Employer contributions under the pay-as-you-go banking pension system (Caja Bancaria) are also higher than in other sectors, and finance generous benefits.

\section{Corporate debt restructuring}

21. The corporate sector remains vulnerable to adverse developments given its high levels of unhedged foreign currency borrowing and high leverage. The private nonfinancial corporate sector had built up large stocks of foreign currency-denominated debt 
prior to the crisis. In 2004, financial liabilities of the private nonfinancial sector were still largely expressed in dollars (foreign currency debt represented 65 percent of total corporate liabilities). When compared to other firms in Latin America, Uruguayan firms feature the highest ratios of liability dollarization, exposing them (and their creditors) to risks from exchange rate fluctuations (Statistical Appendix, Table 15). Although corporate leverage, as measured by the debt-equity ratio, has been reduced since the crisis, the average corporate remains highly indebted and vulnerable to peso depreciation. A substantial number of firms in 2004 exhibited negative net worth as a result of the substantial depreciation of the peso immediately following the crisis.

\section{The corporate debt restructuring process can benefit from reforms to the}

bankruptcy framework. Financial institutions have reported a sharp decline in nonperforming loans. Some of these loans have been restructured, a portion has been written off, and the remainder has been transferred to asset management companies. The high corporate debt levels and large number of firms with negative (book value) equity seem to suggest that corporate nonperforming debts were restructured by extending maturities. The debt restructuring process can be improved by reforming the insolvency legislation to allow for the reorganization of viable firms and the faster and efficient liquidation of unviable ones. The proposed new bankruptcy law envisages major improvements to the current law, including procedures similar to the U.S. Chapter 11 approach.

\section{B. Pension Funds}

23. Uruguay has a defined-benefit public pension system and a defined-contribution pension system managed by financial intermediaries. The public pension system is managed by the Social Security Bank (BPS) and has over one million affiliates, covering about 90 percent of the active adult population. About 670,000 of these employees are also affiliates of the defined-contribution system (AFAPs), which currently manages about US $\$ 2$ billion assets in individual accounts, equivalent to 11 percent of GDP. Employees with wages above Ur\$13,748 are obliged to join the AFAPs; lower-wage workers have an option to join the AFAP system. Employers pay 12.5 percent of salaries and employees contribute 15 percent of their salaries to BPS. While the contribution rates are relatively high by regional standards, a significant proportion of employers' contributions is exempt due to low salaries (Statistical Appendix, Table 16).

24. The public pension system's deficit amounted to 2.6 percent of GDP at end-2005 and a deficit of 1.5 percent of GDP is projected for 2010, despite the earmarking of a portion of tax revenues (Statistical Appendix, Table 17). The contributions of employers and employees only finance about 50 percent of the public pension system's expenditure, and the central government is required to cover the shortfall. The deficit reflects the aging of the population and exemptions of some employers from contributions but also the lingering effects of the pre-1995 policies of low retirement ages. The current tax reform proposal envisages the removal of sectoral exemptions on social security contributions together with a reduction in the contributions to other sectors. However, while improving efficiency, the changes are not expected to alleviate the deficit of the pension system. 
25. Some sectoral pension schemes outside the BPS/AFAP system may represent a potential risk to the government, notably the financially weak scheme for bank employees (Caja Bancaria). Given the economic and political importance of bank employees, the government may at some point be pressured to inject funds to bail-out the system, although it has no legal obligation to do so. The authorities are considering options to reform the public sectoral schemes.

26. Uruguay's AFAP market is highly concentrated and implicit government guarantees pose potential risks. Two of the four AFAPs account for 74 percent of assets (Statistical Appendix, Table 18). The largest one, state-owned AFAP República, accounts for 56 percent of total AFAP assets and the government effectively guarantees a minimum investment return, representing an unrecognized contingent liability for the government that should be eliminated.

27. Investment regulations governing the AFAPs need to be adjusted to ensure a prudent asset risk diversification of affiliates' investments. Government and central bank debt represent over 80 percent of the AFAP's portfolio while about 10 percent of AFAP's assets are held in cash due to unavailability of private sector issues (Statistical Appendix, Table 19). The return on investment remains low, in particular peso (nominal) and dollar securities have earned negative real interest rates in 2005. Possible measures include:

(a) allowing limited overseas investments in high quality assets; (b) allowing currency and interest hedging instruments to be used by AFAPs to protect against losses; and

(c) broadening the range of private sector instruments for AFAP investment by improving the capital market framework.

\section{Insurance Sector}

28. The Uruguayan insurance sector is small and is dominated by the state-owned BSE, which has 60 percent of life and 67 percent of nonlife business. Insurance penetration remains low compared to regional averages (Statistical Appendix, Table 20). The solvency indicators of the insurance sector have improved since the 2002 crisis, however, profitability remains poor due to high expense rates and low underwriting profits. Furthermore, the private insurance firms' growth has been constrained by BSE's dominance in different business lines and its pricing policies. The government has difficulty in overseeing BSE because the timeliness and quality of its data are weak and its transparency, internal controls, and risk management need improvement.

29. BSE represents a contingent liability to the government. The state is effectively BSE's reinsurer and guarantor. Two particular risks for the government are: (a) BSE's effective monopoly position as provider of annuities, which legally must be indexed to wages and for which there are no good market hedges; and (b) BSE's legal monopoly as a provider of workers' compensation and disability, a high-risk line of business.

30. The strategy going forward should be focused on strengthening the oversight, capital and risk management of the insurance sector. Reforms are needed to improve 
BSE's data quality, pricing policies as well as its accountability and transparency.

Furthermore, encouraging innovation in insurance products and asset allocations is necessary for the sector's profitability, growth, and ultimately, its sustainability.

\section{Capital Markets}

31. Capital markets in Uruguay are small and illiquid. In 2004, equity market capitalization amounted to only 2.2 percent of GDP and trading accounted for a mere 0.5 percent of market capitalization, with only 11 listed firms. Issues of bonds and commercial paper peaked in the latter half of the 1990s at US\$100-200 million annually but have collapsed since 1999. The market's limited size is due to the country's small size, lingering effects of the crisis, supply constraints, the legal and regulatory framework, taxation, and infrastructure issues. A wider use of fideicomisos (trusts) would require lowering and simplifying of the tax burden, standardization of contracts, and availability of expertise able to analyze special features of contracts.

32. The authorities have repeatedly announced their intentions to develop local capital markets. The new draft law on capital markets gives more powers to the regulator (by allowing it to supervise stock exchanges) and the proposed new tax law envisages major simplifications in taxation that would make securitization much easier. However, the powers of the supervisor over market agents, such as to regulate and directly impose penalties on stock exchange brokers, are not enhanced and remain with the exchanges.

33. Key policy initiatives should focus on improving corporate governance and disclosure practices as well as fostering new financing and risk-sharing structures. The draft amendments to the capital market law includes corporate governance provisions that are in line with IOSCO standards. The creation of structured products combining several small issues of varying credit quality with some credit enhancements may allow small- and medium-size companies to offer instruments attractive to pension funds. Similarly, the development of markets for hedging instruments should be supported by the establishment of a reference yield curve for government debt (a task of the Debt Management Unit at the Ministry of Finance) and a speedier establishment of the necessary legal and regulatory basis for such instruments.

\section{E. Financial Market Infrastructure}

\section{Payments and securities settlement systems}

34. The main payments system of the BCU, the Sistema Electrónico de Comunicaciones (SEDEC), does not fully comply with several CPSS Core Principles (CPs), though improvements are underway. The CPSS ROSC is provided in Annex. The BCU is addressing some shortfalls of the existing system to make it fully compliant with the CPSS. A project to migrate the current real time gross settlement(RTGS) payment system to a new platform, AGATA, is underway. Areas for further improvement include the development of clear rules and procedures, the establishment of a secondary processing site, 
and the development of business continuity and disaster recovery plans. A comprehensive external audit of the new system should be conducted once the upgrade is completed.

35. The BEVSA-operated check clearinghouse, a major funds transfer system that handles some large-value payments, does not observe most CPSS core principles (Annex). Payments safety and stability would be greatly enhanced by requiring large-value payments to move to the RTGS system. BEVSA is developing an automated clearinghouse $(\mathrm{ACH})$ to settle electronic credit transfers, direct debits, and other new means of payment. The BCU needs to provide oversight and play a catalytic role in encouraging agreements among potential system users in order to help ACH begin operations on a large scale and with a sound legal backing.

36. The BCU's oversight of the securities settlement framework needs to be strengthened. Security settlement oversight is done in a limited way by the stock exchange in its self-regulatory capacity. This function should be complemented by stronger, adequately resourced $\mathrm{BCU}$ oversight, to increase investor confidence in the market.

\section{Accounting and auditing}

37. International accounting standards are legally required for nonfinancial corporations but are poorly understood and compliance is uneven. Financial corporations are subject to accounting rules established by the BCU and are expected to move to international standards by 2008 .

38. A significant improvement in corporate disclosure is needed to support lending to corporates and to develop the capital market. Public disclosure of financial information is required for most companies, but not adequately observed, except for banks and issuers of market instruments, where BCU pressure has brought improvement. The quality of information is also uneven, even among listed companies. Disclosure of ownership is also limited. These weaknesses in information complicate lending by financial institutions, enforcement of regulatory rules on exposure, and capital market development.

\section{The Financial Stability Policy Framework}

\section{A. Independence of Central Bank and Regulatory Institutions}

39. The proposed amendments to the BCU's charter are aimed at improving the autonomy and accountability of the central bank. The draft law aims to enhance the governance structure of BCU by delinking the appointment cycle of the BCU's board from the electoral cycle. The draft law grants the BCU operational autonomy but further modifications are needed to improve its budgetary autonomy. A key amendment incorporated in the draft law is the provision of legal protection to BCU staff in fulfillment of their duties. The draft law also tightens the financial reporting standards of the BCU by requiring the publication of its audited financial statement in accordance with international accounting standards. 
40. The BCU plans to reorganize its financial supervision and regulation functions as a separate autonomous unit within the central bank. The proposed amendments to BCU's charter envision the unification of the banking, insurance, securities, and pensions regulation under a newly-created Superintendency of Financial Services. The motivation for this integration is the need to improve the supervision of financial conglomerates.

\section{B. Regulation and Supervision}

41. The Superintendency of Banks has made significant progress in the regulation and supervision of the banking system since the 2002 banking crisis. First, it improved the efficiency of its operations. Second, it increased the disclosure of financial information, which contributed to greater market discipline. Finally, it introduced a series of prudential limits to reduce exposures and concentration of risks. It also overhauled the loan classification and capital requirement regulations. A summary of these measures is presented below (Box 3). Statistical Appendix, Table 21 provides a detailed chronology of measures taken.

\section{Three key problems common to all sectors hinder the effectiveness of financial} sector oversight-lack of resources, limits on powers over state institutions, and quality of data provided by state institutions. First, all of the superintendencies within the BCU lack sufficient resources. While technically competent, staff is generally overstretched and funding for information systems and training in up-to-date supervisory methods and financial practices is scarce. Access to resources from multilateral organizations has allowed to partially overcome these constraints, but these resources are temporary. Second, the supervision of public financial institutions is limited by the legal framework. The capacity of supervisors to enforce corrective actions is limited by their inability to require changes in management of public financial institutions. Third, the quality and timeliness of data provided by the public financial institutions remains a problem that affects the ability to oversee public financial institutions. These issues are reflected in the assessment of compliance with the Basel Core Principles for Effective Bank Supervision (BCP) which indicates that, in spite of recent progress, additional improvement is required (see Annex).

43. Regarding the insurance sector, the regulation and supervision of composite companies, annuities and BSE should be improved. There is a need to strengthen capital and provisioning rules and financial reporting, including a review of the treatment and transparency of reinsurance. Companies providing annuities need to be better supervised in terms of capital and financial reporting standards. These improvements should be implemented before annuity growth accelerates as AFAP retirees begin to grow in number. 


\begin{tabular}{|c|c|}
\hline \multicolumn{2}{|c|}{ Box 3. Measures Taken to Address Liquidity, Market, and Credit Risks } \\
\hline Risks to be Addressed & Measures Taken \\
\hline - Liquidity risk arising from dollarization & $\begin{array}{l}\text { - Imposed higher reserve requirements on foreign } \\
\text { exchange deposits. }\end{array}$ \\
\hline - Liquidity risk from cross-border exposure & $\begin{array}{l}\text { - Increased the } 25 \text { percent liquidity requirement on } \\
\text { nonresident deposits to } 30 \text { percent. }\end{array}$ \\
\hline - Credit risk arising from dollarization & $\begin{array}{l}\text { - Imposed higher capital requirements for foreign } \\
\text { currency credit; increased risk weight of FX } \\
\text { loans to } 125 \text { percent. The overall required capital } \\
\text { adequacy ratio was reduced from } 10 \text { to } 8 \text { percent. }\end{array}$ \\
\hline & $\begin{array}{l}\text { Amended loan classification and provisioning } \\
\text { rules to take into account the sensitivity of } \\
\text { capacity to repay to changing market conditions, } \\
\text { including movements in the exchange rate. }\end{array}$ \\
\hline & $\begin{array}{l}\text { - Imposed strict criteria for classification of } \\
\text { foreign currency consumption and housing loans } \\
\text { (rated } 3 \text { if debt service higher than } 15 \text { percent } \\
\text { and } 30 \text { percent of household income for FX } \\
\text { loans and domestic currency loans, respectively). }\end{array}$ \\
\hline - Credit risk arising from cross-border exposures & - Set limits on country exposures. \\
\hline - Foreign exchange risks & $\begin{array}{l}\text { - Imposed capital requirements for FX open } \\
\text { positions. }\end{array}$ \\
\hline - Market risks & $\begin{array}{l}\text { - Introduced capital allocation for market risk as } \\
\text { of June } 2006 \text {. }\end{array}$ \\
\hline $\begin{array}{l}\text { - Cross border risks, including risks from the } \\
\text { operation of cross border financial } \\
\text { conglomerates }\end{array}$ & $\begin{array}{l}\text { - Signed MOU with Spain and initiated procedures } \\
\text { to sign MOUs with Argentina and other } \\
\text { countries. }\end{array}$ \\
\hline
\end{tabular}

\section{Anti-money laundering procedures}

\section{The current AML/CFT regime is largely underdeveloped but there is political commitment to introduce the necessary reforms. ${ }^{3}$ Recent steps have been taken to address}

\footnotetext{
${ }^{3}$ The AML/CFT regime of Uruguay was assessed in November 2005 by a team led by Fund staff. The detailed assessment report will also be used by GAFISUD (the Financial Action Task Force of South America) for purposes of its mutual evaluation of Uruguay, and will be presented by Fund staff during GAFISUD's Plenary scheduled for July 20-21, 2006. The detailed assessment report and accompanying ROSC will be finalized after the Plenary discussions, and the ROSC will be submitted to the Executive Board therafter.
} 
some of the weaknesses in the AML/CFT regime including the passage of new AML/CFT legislation and initial work to build institutional structures to support implementation.

45. Uruguay has put in place many of the basic legal elements for an AML/CFT regime. However, the legislation should be improved including coverage of a broader range of predicate offences for money laundering. Confiscation provisions are generally sound but the efficiency of property registries should be enhanced to support implementation.

46. Uruguay serves as a regional offshore financial center which makes it particularly vulnerable to $\mathrm{ML} / \mathrm{FT}$ arising from its transnational businesses operations. Deficiencies in the supervision and implementation of AML/CFT requirements in key sectors (e.g., securities, corporate services, and casinos) also add to these risks. To help mitigate these risks, the government plans to introduce legislation that would overtime discontinue the registration of Uruguayan offshore companies. Improvements in supervisory capacity across all sectors, but particularly in the nonbanking sector, are also required (Appendix II provides a summary of key recommendations).

\section{Safety nets and crisis management}

47. Powers to resolve problem banks have been enhanced since the 2002 crisis, but additional measures are necessary. In December 2002, congress approved legislation that allowed the BCU to resolve the ongoing crisis and granted it additional powers to supervise banks, impose corrective actions, and resolve problem cases. It is recommended that, in addition to the above-mentioned discretionary powers, the law establish a framework for prompt corrective action and clarify the role of the BCU as liquidity provider "under extreme circumstances."

48. Draft legislation establishes the deposit insurance agency (COPAB) as an autonomous institution outside of the $\mathrm{BCU}$ with the responsibility for the resolution and liquidation of problem institutions. The draft law calls for the COPAB to develop a decision-making and accountability framework for the least-cost resolution process and it appropriately includes the legal protection for COPAB staff while in fulfillment of their duties. The deposit insurance fund became operational in 2005.

49. The staff recommended that the authorities develop a comprehensive contingency plan to allow them to identify probable solutions for alternative crisis scenarios, test these solutions and the effectiveness of the implementation arrangements in place, and identify weaknesses to be addressed. The plan should define the roles of each of the parties involved in managing a crisis and the means for effective coordination (BCU, COPAB, MoEF and private institutions). 


\section{REPORTS ON OBSERVANCE OF STANDARDS AND CODES}

The annex contains summary assessments of two international standards and codes relevant for the financial sector. The assessments have helped identify the extent to which the supervisory and regulatory framework is adequate to address the potential risks in the financial system.

The following detailed assessments of financial sector standards were undertaken:

- $\quad$ The Basel Core Principles for Effective Banking Supervision (BCP), by Ernesto Livacic and Walter Zunic (both consultants).

- $\quad$ The Core Principles for Systemically Important Payments Systems (CPSIPS), by Mario Guadamillas (World Bank).

The assessments were carried out during two missions to Uruguay in October 2005 and JanuaryFebruary 2006 and are based on the laws, regulations, policies and practices in place at the time the assessments were made.

The assessments were based on several sources including: (a) Self-assessments by the supervisory authorities; (b) Reviews of relevant legislation, regulations, policy statements and other documentation; (c) Detailed interviews with the supervisory authorities; (d) Meetings with the Central Bank of Uruguay, Ministry of Economy and Finance, and other authorities and independent bodies; and (d) Meetings with financial sector firms and associations.

\section{Basel Core Principles For Effective Banking Supervision}

\section{Institutional and macroprudential setting, market structure-overview}

50. There has been a conscious effort to address the weaknesses of the regulatory and supervisory framework evidenced during the 2002 banking crisis. At the onset of the crisis, the law of financial institutions was amended to facilitate crisis resolution, empower the BCU to conduct consolidated supervision, and require BCU approval for transferring the ownership of financial institutions. More recently, an internal reorganization took place to focus the SIIF on the key supervisory processes and improve its efficiency. As a result, the SIIF is moving toward a risk-based approach to supervision, has implemented processes to conduct consolidated supervision, and has taken a more proactive approach to corrective actions. Disclosure of financial information was significantly increased to foster market discipline. Prudential regulation was strengthened by approving a series of limits to exposures and concentration of risks and tightening loan classification and capital requirements. Finally, measures to mitigate the vulnerabilities from dollarization and crossborder contagion were also implemented.

51. Notwithstanding all this progress, the assessment of compliance with the Basel Core Principles for Effective Bank Supervision (BCPs) identified several areas where further improvement is needed. Out of 30 core principles (CPs), 21 are assessed in the compliant category of which 9 are fully compliant and 12 are largely compliant. The other 9 CPs are in the materially noncompliant category. 
52. The main weaknesses are concentrated in four key areas. First, operational independence of bank supervision is restricted by the lack of a clear and stable source of funding and the capacity of the executive branch to overturn decisions made by the BCU board. These - compounded by the lack of explicit legal protection for bank supervisors and for the BCU board - could hamper the effectiveness of bank supervision, particularly during stressful periods. Second, the remedial capacity of the SIIF with regards to state-owned banks is limited by its inability to remove and to establish fit and proper requirements for directors and senior managers of these institutions, and its lack of authority to impose the most severe sanctions to these banks. The supervisor can impose alternative measures to affect the behavior of public banks, including high liquidity requirements. Third, regulation and supervision of market and other risks has not been fully implemented. Finally, accounting norms for banks depart in a number of respects from international accounting standards (IAS).

53. The authorities are taking measures to address most of these weaknesses. Amendments to the BCU charter were submitted for congress' approval to strengthen the autonomy of the BCU. The BCU's autonomy would be enhanced by: (a) extending the terms of office of BCU directors, so that they do not coincide with the election cycle;

(b) establishing only two clear goals for the BCU, price stability and the regulation and supervision of the financial sector; and (c) eliminating the faculty of the executive branch to overturn decisions of the BCU board and replacing it by a clear accountability mechanism. A regulation requiring capital charges for market risk will be effective in June 2006 and the SIIF is in the process of drafting a new regulation that would establish risk management requirements for all risks faced by financial institutions. The BCU intends to issue the new chart of accounts by end-2006 to make accounting rules fully consistent with IAS, with mandatory full compliance by end-2008.

\section{Main findings}

\section{Preconditions for effective banking supervision (CP 1)}

54. The Uruguayan constitution grants autonomy to the BCU and the legal framework for the regulation and supervision of the financial sector provides an adequate basis for prudential regulation. It grants the BCU and the SIIF significant flexibility and authority to introduce specific regulations as necessary. However, the operational independence of the SIIF is affected by the absence of a clear and stable legal basis for the BCU's financial resources, and consequently of the resources available for supervision. In addition, the executive branch has the power to suspend or amend decisions made by the BCU board. The current legal framework does not provide legal protection for the supervisory agency and its staff for actions taken in the fulfillment of their duties in good faith. Approval of the draft law submitted to congress in December 2005 would address these drawbacks.

55. The BCU does not have the authority to remove directors of state-owned banks. The BCU should be able to apply same type of remedial powers over both private and public banks. The lack of specific powers to undertake rigorous corrective measures in the case of public banks may lead to differential regulatory treatment and create distortions. 


\section{Licensing and structure (CPs 2-5)}

56. The current framework clearly defines the eligibility criteria for institutions that can operate as a bank and their shareholders and managers, and enables the SIIF to assess the ownership structure of banks. The executive branch grants banking licenses based on the recommendation of the $\mathrm{BCU}$. In order to start operations, financial institutions must also have the authorization of the BCU. The licensing process includes a fit and proper assessment of shareholders and managers of banking institutions. Acquisition of shares in foreign banks, pension and investment funds, and investment banks also requires prior authorization from the BCU.

\section{Prudential regulation and requirements (CPs 6-15)}

57. Rules and regulations regarding capital adequacy generally conform to the 1988 Basle Capital Accord, but regulations on capital for market risk will only become effective as of June 2006. Changes in capital requirements applying a higher weight to foreign currency loans (125 percent) relative to domestic currency loans (100 percent) while reducing the overall capital requirement from 10 percent to 8 percent, will also be effective in June. Capital adequacy requirements apply equally to all banks.

58. The recently revised framework for the control of credit risks is deemed generally adequate. Tightened-loan classification and provisioning rules, effective as of January 2006, have increased the loan classification categories from five to eight, increasing the sensitivity to risk. Banks have also been required to assess the sensitivity to changes in market conditions of the capacity to repay of their large borrowers.

59. The supervision of market risks and other risks does not conform to international standards. The SIIF has instituted suitable policies and procedures related to the identification, measurement, monitoring, and control of market risk. It has also created a specialized unit that conducts the analysis of market and liquidity risk. However, supervisors are yet to reach a level of understanding of market risk sufficient to assess the level of complexity of banks' market risks. The SIIF is yet to issue guidelines or regulations with respect to interest rate risk and non-IT operational risks.

60. The anti-money laundering process is assessed as materially noncompliant. Supervision of compliance with anti-money laundering regulations should be enhanced in those areas identified as posing a higher degree of money laundering risk, and should be conducted on a consolidated basis. To complement such supervision, the BCU should also consider ways to maximize the use of the annual AML compliance reports prepared by the external auditors, including for enforcement of compliance.

\section{Methods of ongoing supervision (CPs 16-20)}

61. The implementation of supervision by SIIF is on a consolidated basis, comprehensive, proactive, focused on risks, and emphasizes the importance of corporate governance. The on-site examinations are full-scale and focused. The SIIF's various teams work in close cooperation and thus are able to arrive at a qualitative identification and understanding of the risks faced by the institutions they examine. The examiners utilize an 
in-house rating system (CERT) to inspect the banks. The supervisors are doing a competent job in providing an objective evaluation of the quality of an institution and identifying areas where corrective action is required.

62. The reporting system is adequate and allows the supervisors to identify potential problems and risks assumed by banks in a timely manner. Banks are required to provide a considerable amount of information, including daily submission of the bank's statements. The SIIF collects monthly consolidated financial information for each bank. The SIIF has the authority to impose prudential standards on a consolidated basis for bank.

\section{Accounting standards (CP 21)}

63. There are significant differences between the BCU chart of accounts and international accounting standards. These relate to the accounting of derivatives, the accrual of labor benefits and taxes, and the insufficient information in audited financial statements that would allow analysts to estimate divergence from IAS. The BCU is contracting consultants to bring the chart of accounts in line with international standards. BCU contemplates that the process of updating the chart of accounts will be completed by end-2006 and that full compliance with the IAS by all banks will commence at end-2008.

\section{Formal powers of supervisors (CP 22)}

64. The BCU and the SIIF have the power to take an appropriate range of remedial actions against private banks, but have limitations regarding the actions that can be taken against state-owned banks. The BCU board, upon the recommendation of the SIIF, approves the most severe sanctions and actions, while the SIIF issues lesser sanctions and a broad range of remedial instructions. State-owned institutions can be subject to most remedial measures except for the ability to intervene or change their management. Additionally, while the BCU can impose fines on directors and managers of state-owned institutions, this has never been done. Since the crisis, however, the SIIF has started to impose very stringent remedial measures on state-owned institutions, including special reserve requirements and severe limitations on their operations.

\section{Cross-border banking (CPs 23-25)}

65. The SIIF has the authority and powers to supervise internationally active banks but has not signed MOU's with the supervisors of Argentina, Brazil, and the United States, where local financial institutions conduct their activities. The SIIF has the power to carry out necessary on-site examinations that adequately review the overseas activities of branches of local banks and has regular contacts with the foreign supervisors of these operations.

66. Subsidiaries and branches of foreign banks and offshore offices are subject to the same prudential, inspection, and regulatory reporting requirements as domestic banks. The BCU has the authority to require the closing of a foreign bank entity, including offshore offices, if it determines that host-country supervision is inadequate. Currently there are six offshore offices owned by large foreign financial institutions. The SIIF has signed an MOU with the Bank of Spain and is in the process of drafting projects for agreements with 
Argentina and other countries that have a presence in Uruguay and that have expressed interest in signing bilateral agreements.

\section{Authorities' response}

67. The Uruguayan authorities agreed with most of the assessment and have already taken action to implement several recommendations. However, they disagree with the assessment of the principles on anti-money laundering (CP 15) and accounting (CP 21). They indicated that they assign a high priority to complying with best practices regarding antimoney laundering. The authorities have taken recent measures to address some of the weaknesses in the AML/CFT regime including the passage of new AML/CFT legislation and initial work to build institutional structures to support implementation. With regard to CP 21, they noted that the accounting rules in Uruguay are generally consistent with IAS. 


\section{Table 2. Recommended Action Plan to Improve Compliance with the Basel Core Principles 1/}

\begin{tabular}{|c|c|}
\hline Reference Principle & Recommended Action \\
\hline CP 1.2-Independence and Resources & $\begin{array}{l}\text { Additional resources should be channeled to fund } \\
\text { personnel, training, and IT systems. }\end{array}$ \\
\hline CP 1.4-Enforcement powers & $\begin{array}{l}\text { Regulations to be adapted to apply the same fit and } \\
\text { proper requirements of directors of commercial banks } \\
\text { to directors of state banks. }\end{array}$ \\
\hline CP 1.5-Legal protection & $\begin{array}{l}\text { Legislation to be amended to protect supervisory staff } \\
\text { against legal actions for measures taken in carrying out } \\
\text { their duties (addressed by pending legislation). }\end{array}$ \\
\hline CP 1.6 & $\begin{array}{l}\text { SIIF to sign MOUs with home country supervisors of } \\
\text { foreign banks. }\end{array}$ \\
\hline CP 6-Capital Adequacy & $\begin{array}{l}\text { Ensure successful implementation by the banks of } \\
\text { market risk capital requirements. }\end{array}$ \\
\hline CP 11-Country Risk & $\begin{array}{l}\text { Ensure that the financial institutions are taking the } \\
\text { required measures to implement country limits in order } \\
\text { to provide for the capital provisioning requirements } \\
\text { established by the new Regulation to take effect in } \\
\text { January } 2006 \text {. }\end{array}$ \\
\hline CP 12-Market risks & $\begin{array}{l}\text { The banking supervisors have to reach a more } \\
\text { proficient level of understanding market risks and } \\
\text { require additional training in order to analyze and } \\
\text { monitor the level of complexity in the market activities } \\
\text { of the banks. }\end{array}$ \\
\hline CP 13-Other risks & $\begin{array}{l}\text { Issue a regulation that addresses the total risks of an } \\
\text { institution and requires the introduction of a } \\
\text { comprehensive system of risk control. The SIIF is } \\
\text { preparing a draft of such a regulation. }\end{array}$ \\
\hline CP 15-Money laundering & $\begin{array}{l}\text { An explicit requirement to identify beneficiary } \\
\text { customers is needed. Additional training is required for } \\
\text { the analysts of the UIAF unit that are required to liase } \\
\text { with other relevant authorities (addressed by pending } \\
\text { legislation). }\end{array}$ \\
\hline CP 16-On-site and off-site supervision & $\begin{array}{l}\text { Additional data systems specialists should be assigned } \\
\text { on a permanent basis to the SIIF. Focused training of } \\
\text { supervisors in the areas of credit analysis and market } \\
\text { risks is required. }\end{array}$ \\
\hline CP 21-Accounting Standards & $\begin{array}{l}\text { Take measures to ensure that banks implement IAS in } \\
\text { the preparation of } 2008 \text { financial statements. }\end{array}$ \\
\hline CP 22-Remedial Measures & $\begin{array}{l}\text { Issue a regulation that defines the timing and } \\
\text { circumstances to implement the specific corrective } \\
\text { actions listed in the legislation. }\end{array}$ \\
\hline
\end{tabular}

$1 /$ It is assumed that the financial sector law will be enacted as submitted. 


\section{CPSS CORE Principles For Systemically IMPORTANT PAYMENT SystemS}

\section{Payment and securities settlement systems infrastructure}

\section{Payment systems}

68. Cash and checks are the major means of retail payments in Uruguay. There is a single national check clearinghouse in local currency and in U.S. dollars regulated by the central bank and operated by Bolsa Electrónica de Valores del Uruguay (BEVSA), a private sector entity owned by the banking sector. BEVSA settles the outgoing balances at the BCU. Checks can be endorsed several times without any limit. Exchange of physical items takes place between 11:00 p.m. and 11:45 p.m. Checks information is sent to BEVSA by banks before 12:30 a.m. on $\mathrm{T}+1$. On $\mathrm{T}+1$ between 10:30 a.m. and 11:30 a.m. a rejected items session takes place and new debit positions are settled at BCU accounts. The BCU ensured settlement even if no funds were available in the banks' accounts at BCU until August 2005. Currently, the BCU provides collateralized credit for a maximum value of 15 percent of the Responsabilidad Patrimonial Neta (with a cap of two times the minimum amount required to create a bank in Uruguay, Responsabilidad Patrimonial Básica) or the market value of securities available to collateralize, whichever is lower. ${ }^{4}$ BCU and government securities are accepted as collateral with the application of a haircut.

69. There is a funds transfer system operated directly by the BCU that affects the accounts financial institutions hold at the central bank through Sistema Electrónico de Comunicaciones (SEDEC). In addition to the automated system, participants are still able to move funds in their accounts with Cartas (paper instructions). The great majority of payments are denominated in local currency or U.S. dollars, although participants can also request transactions in other currencies like the euro. Banks have access to credit from the BCU for payment system purposes. Since August 2005 this credit facility is collateralized as explained in the paragraph above. Reserve requirements can be mobilized throughout the day. Although in principle banks have to comply with a monthly average, only in four days of the month the reserves could be under the established limit in the case of local currency and never below 90 percent in the case of foreign currency. The funds transfer system within SEDEC is migrating to a new platform, AGATA.

70. Regarding other cashless payment instruments, debit cards and credit cards use is still very limited. There are 5 major credit card issuing companies, OCA, VISA, MASTERCARD, DINERS and AMEX. Settlement of card transactions takes place through the local networks in the case of OCA and VISA, regional networks (Argentina) in the case of MASTERCARD, and international networks for the rest. Debit cards are used almost exclusively for cash withdrawals. There are 4 major ATM networks, BROU, REDBANC, BANCOMAT, and CABAL with more than 575 ATMs. The two major private sector networks, REDBANC and BANCOMAT merged in July 2005. There is not a national Electronic Funds Transfer at Point of Sale (EFTPOS) switch. In addition, there are two

\footnotetext{
${ }^{4}$ See BCU Circulares 1931 of May 2005 and 1934 of August 2005.
} 
companies that provide payment services (payment and collection of utilities and taxes), Abitab and Red Pagos, with about 900 agencies throughout the country.

71. Regarding cross-border payments, the BCU and the commercial banks are connected to SWIFT. Normally banks send funds to their foreign correspondents through the BCU. In some cases, related to export/import activity, commercial banks and other nonbank financial institutions send payment instructions directly through SWITF (via BEVSA network).

Remittances are not a very important source of funding for Uruguay. Net Inbound remittances in 2004 represented approximately 0.5 percent of GDP.

\section{Securities settlement systems}

72. Securities markets in Uruguay are dominated by central bank and government securities. The government issues treasury bills (letras del tesoro), which are short-term securities, and treasury bonds (bonos del tesoro), which are long-term securities. The Government also issues peso securities indexed to the CPI and securities in foreign currency and foreign markets, "Global Notes and Bonds." The BCU issues short term securities for monetary policy purposes (Letras de Regulación Monetaria) denominated in peso and CPIindexed units. Private sector securities consist of certificates of deposits (CDs), stocks and negotiable bonds. However, operations of private securities are very limited with trading in only one stock and five negotiable bonds. The securities market activities are concentrated in two exchanges, the Bolsa de Valores de Montevideo (BVM) created in 1867 and the Bolsa Electrónica de Valores (BEVSA) created in 1993. Total stock exchange operations in 2004 amounted to approximately US\$2,203 million of which 42 percent was done through the BVM and 58 percent through the BEVSA. Out of total stock exchanges operations 47 percent of the value was primary market activity and 53 percent trading in the secondary market. In 2005, the domestic primary market has been almost inexistent as the government has issued in foreign markets (global notes and bonds). Most of the activity is in public securities except trading in CDs. There is also an important trading of foreign securities due to the lack of domestic securities. As of October 2005, there were 74 registered brokerdealers in the BVM although only 35 are active. BEVSA is owned by 17 shareholders including all the banks and has 9 special partners that do not own the company but are allowed to be direct operators. All the four AFAPs (Administradoras de Fondos de Ahorro Previsional) are special partners.

73. Securities are issued in dematerialized (escriturales) or physical form. BVM activity is undertaken at the floor of the exchange from 2:00 p.m. to 2:30 p.m. and from 4:15 p.m. to 5:00 p.m. No electronic trading system operates at the moment. Confirmation process takes place in the 30 minutes following closing of the trading. Settlement takes place on $\mathrm{T}+1$ for domestic securities and $\mathrm{T}+3$ for securities issued in foreign markets at 5:00 p.m. (time at which bank offices close) on a gross basis for securities and multilateral net basis for funds. Physical securities and global securities are under custody in one private bank (ABN Amro). Currently the BVM is reaching an agreement to change this arrangement. Physical securities will be under custody of a domestic bank and global securities under custody by a correspondent bank in New York. Government and central bank dematerialized securities are 
deposited in the BCU under the name of the BVM. ${ }^{5}$ Once the BVM receives the funds through the ABN Amro funds settlement account or in its account at the central bank via the SEDEC system, the BVM transfers the ownership (delivers if physical) the securities. If securities or funds are not delivered at settlement time the BVM rules include buy-in and sell-out procedures at the cost of the failing party through its Generic Stock Exchange Guarantee. BEVSA operates an electronic trading system opened from 10:00 a.m. to 5:00 p.m. that is connected on-line with the BCU securities custody system (AGATA). For securities under BCU custody, settlement takes place on a gross basis real-time for both securities and funds. Trading in other securities is settled bilaterally. Global securities settlement takes place bilaterally through international custodians on $\mathrm{T}+3$. The OTC market is important although there are no official figures. Broker-dealers can trade through the stock exchange or in the OTC market but they have to inform on all its operations. OTC transactions are settled bilaterally.

\section{Legal framework}

- $\quad$ The BCU Charter (Carta Orgánica del Banco Central del Uruguay) dated March 30, 1995, includes as a basic function of the BCU "to ensure a smooth functioning of the domestic and foreign payments" (Article 3b). Thus, the law is specific about the role of the central bank in payment systems as it establishes the basis for its regulatory and oversight powers (although not explicitly) and, if necessary, for the operation of some systems if necessary. Articles 6 and 26 regulate the issue of currency and its legal tender. In addition, the law empowers the BCU to establish arrangements with private and public institutions regarding payments and its settlement (Article 29). This law also regulates reserve requirements (Article 27), open market operations, and financial assistance (Articles 27, 36 and 37). Article 55 refers to the securities issues by the central bank.

- $\quad$ Regarding securities settlement, the securities markets law (Ley del Mercado de Valores), approved in May 2, 1996, includes the legal basis for the immobilization and dematerialization of private securities (Articles 7 to 12). It is uncertain if the SML is applicable to public securities as Article 1 seems to exclude them from the application of the law. Article 45 regulates the approval by the BCU of the securities depositories. The stock exchanges are considered as self-regulatory-organizations (SROs) in all aspects of their activity (Article 15), including securities settlement. The BCU is the entity in charge of securities market regulation and supervision (Article 20).

\section{Main findings}

74. The Sistema Electrónico de Comunicaciones (SEDEC) is the main operating system of the BCU. Within it, there is a module through which some of the institutions holding a current account at the BCU may transfer funds among them under a RTGS mode. Due to the high value

\footnotetext{
${ }^{5}$ In December 2005 the BVM account will identify the broker-dealer.
} 
settled through it, this funds transfer system is considered systemically important. The check clearinghouse operated by BEVSA is also a major funds transfer system in the country; checks are sometimes used as an instrument for the exchange of large value payments. The check clearinghouse still presents some elements of systemic importance.

Table 3. Uruguay: Systemically Important Payments, 2004

\begin{tabular}{lccccc}
\hline System & $\begin{array}{c}\text { Number of } \\
\text { Participants }\end{array}$ & $\begin{array}{c}\text { Daily Value of } \\
\text { Instructions } \\
\text { Handled } \\
\text { (In millions of } \\
\text { U.S. dollars) }\end{array}$ & $\begin{array}{c}\text { Average Value } \\
\text { per } \\
\text { Transaction } \\
\text { Settled } \\
\text { (In U.S. } \\
\text { dollars) }\end{array}$ & $\begin{array}{c}\text { Daily } \\
\text { Volume of } \\
\text { Instructions } \\
\text { Handled }\end{array}$ & $\begin{array}{c}\text { Yearly } \\
\text { Value of } \\
\text { Transactions } \\
\text { over GDP } \\
\text { (In percent) }\end{array}$ \\
\hline $\begin{array}{l}\text { SEDEC- } \\
\text { AGATA } \\
\text { Checks }\end{array}$ & 181 & 129 & 204,408 & 633 & 236 \\
\hline Sours & 15 & 78 & 1,570 & 49,780 & 143 \\
\hline
\end{tabular}

Source: BCU.

75. The BCU does not observe fully some of the CPs and responsibilities in applying the CPSIPS. It therefore needs to establish formally its oversight function over the payment system as a whole and have the ability to exercise its oversight function effectively. Important efforts to upgrade the payment system and integrate the government securities infrastructure with the large-value system should be put in place soon, to guarantee both the smooth functioning of the payment system and the creation of a more active market for government securities. It is recognized that the BCU's reform program will address many of the weaknesses in the payment and securities settlement system. The authorities are encouraged to make early implementation of the program a priority.

\section{Authorities' response}

76. Authorities were in agreement with the assessment. 
Table 4. Recommended Actions to Improve Observance of CPSS Core Principles

\begin{tabular}{|c|c|}
\hline Reference Principle & Recommended Action \\
\hline $\begin{array}{l}\text { Legal foundation } \\
C P 1\end{array}$ & $\begin{array}{l}\text { Pending legal issues should be addressed as a priority by the BCU, including the } \\
\text { finality of settlement, protection of the systems against bankruptcy procedures, } \\
\text { legal basis for netting arrangements, legal basis for public securities, legal } \\
\text { definition of the repo, improvement of the legal basis for custody arrangements } \\
\text { and legal basis for electronic signatures and documents. }\end{array}$ \\
\hline $\begin{array}{l}\text { Understanding and } \\
\text { management of risks } \\
C P S 2-3 \\
\end{array}$ & $\begin{array}{l}\text { The BCU should develop a clear strategy to effectively migrate all large-value } \\
\text { payments from the check clearinghouse to the RTGS system. }\end{array}$ \\
\hline \begin{tabular}{|c|} 
Settlement \\
CPS 4-6 \\
\end{tabular} & $\begin{array}{l}\text { Amendments to legislation regarding irrevocability of a settled payment are } \\
\text { necessary. }\end{array}$ \\
\hline $\begin{array}{l}\text { Security and operational } \\
\text { reliability, and contingency } \\
\text { arrangements } \\
\quad C P 7\end{array}$ & $\begin{array}{l}\text { Some shortfalls in the existing funds transfer system are already being } \\
\text { addressed. Areas that require further measures include: } \\
\text { i) setting-up of a secondary processing site; } \\
\text { ii) definition and implementation of a broader business continuity plan } \\
\text { (BCP) as well as a disaster recovery plan (DRP) and test them on a } \\
\text { regular basis; } \\
\text { iii) periodic training and tests of these procedures are recommended; } \\
\text { iv) the re-location of the back-up servers to a location with a different risk } \\
\text { profile compared to the main site; } \\
\text { v) strict enforcement of security requirements to overcome possible risks } \\
\text { which might be brought into the system by the participants. } \\
\text { vi) training programs for the participants to increase the system security as } \\
\text { well as participants' awareness regarding safety and efficiency issues. } \\
\text { The BCU is undertaking an important upgrade of the current RTGS system. Due } \\
\text { to its systemic importance it is recommended to undertake a comprehensive } \\
\text { external audit of the system once the upgrade has been completed. }\end{array}$ \\
\hline $\begin{array}{l}\text { Criteria for participation } \\
\quad C P 9\end{array}$ & $\begin{array}{l}\text { The BCU should develop clear access criteria and also define criteria regarding } \\
\text { the exclusion of participants from the system. Samples to establish and adapt } \\
\text { these requirements to needs of the BCU are available at various RTGS } \\
\text { operators. This measure would ease all the participants and increase the } \\
\text { confidence into the system as a whole. }\end{array}$ \\
\hline $\begin{array}{l}\text { Governance of the payment } \\
\text { system } \\
\quad C P 10\end{array}$ & $\begin{array}{l}\text { It is recommended the creation of a system users' group to support the BCU and } \\
\text { in general the Payment System Council and its working groups in terms of } \\
\text { initiating new services, accelerating the development of the system, and } \\
\text { enhancing the compliance with the user needs, thereby emphasizing and } \\
\text { improving the governance function significantly. }\end{array}$ \\
\hline
\end{tabular}




\begin{tabular}{|c|c|}
\hline Reference Principle & Recommended Action \\
\hline $\begin{array}{l}\text { Central Bank } \\
\text { Responsibilities in applying } \\
\text { the CPs } \\
\text { i.e., Responsibilities } A-D\end{array}$ & $\begin{array}{l}\text { The BCU in exercising its oversight role should have the ability to carry out this } \\
\text { function effectively. To this end, the BCU should establish appropriate } \\
\text { organizational arrangements and staffing. This includes the smooth integration of } \\
\text { functions between the role of the central bank as payment system operator and its } \\
\text { responsibility as payments system overseer. It is important the formation of a } \\
\text { small unit of people in charge of payment system oversight, whose activities } \\
\text { should be separated to the extent possible from the units in charge of operating the } \\
\text { systems offered by the central bank. } \\
\text { Important actions will need to be carried out by the BCU as payment system } \\
\text { overseer: (1) ensure that an adequate degree of participant cooperation exists; } \\
\text { (2) verify that individual payment systems satisfy user needs; (3) define and } \\
\text { implement appropriate actions should participants not comply with published rules } \\
\text { and regulations; (4) collect and distribute relevant statistical information to } \\
\text { demonstrate the use being made of each system and the extent to which the } \\
\text { systems are satisfying end-user and other market needs. } \\
\text { The BCU should move toward compliance of all systemically important payment } \\
\text { systems in the country with international standards. To this end, the BCU should } \\
\text { continuously review and seek to improve the design and operation of the systems. }\end{array}$ \\
\hline
\end{tabular}




\section{Methodological Aspects of Stress Testing in the URUguay FSAP}

77. As part of the FSAP, stress tests were conducted on the main banking institutions to assess their resilience to a variety of potential shocks. The banking institutions included all private banks, cooperative banks, finance companies, offshore banks, and the state-owned Banco de La República Oriental del Uruguay (BROU), representing 80 percent of financial system assets. The stress tests were performed on exposures, on a bank-by-bank basis, as of June 2005. This note describes the methodology used.

\section{Sensitivity analysis}

78. The exposure to exchange rate risk was measured by the net open position of individual institutions. As U.S. dollar-denominated assets and liabilities accounted for most of assets and liabilities, the net open position was stressed against a depreciation and an appreciation of the U.S. dollar-peso exchange rate of 30 percent (equivalent to one standard deviation of the changes in the exchange rate) over a year.

79. The exposure of the banking system to interest rate risk was assessed using two methods. First, the impact on banks' trading book of the effect of changes in interest rates was estimated. Given a change in the U.S. dollar, peso, and indexed-unit yield curves, the BCU repriced the securities in the banks' trading book accordingly and marked them to market. ${ }^{6}$ This allowed to quantify the effect of the losses or gains arising from changes in interest rates on banks' capital and risk-weighted assets. Second, the impact of changes in the yield curves on the net present value of banks' cash flows was estimated. ${ }^{7}$ This is equivalent to an asset-liability management framework, where both asset and liability cash flows are discounted at the appropriate spot rates implied by the U.S. dollar, peso, and indexed-unit yield curves. Even though not all assets and liabilities are marked to market, and there is no immediate impact of changes in the yield curves on the banking book, profitability is affected over time as long-term assets are increasingly funded by more costly short-term liabilities.

80. Table 5 shows the changes in the U.S. dollar, peso, and indexed-unit yield curves proposed for the interest rate stress tests. The size of the shocks were calibrated using historic information. The first shock was a parallel shift of the U.S. dollar (for domestic and foreign assets) and peso (for peso and indexed-unit assets) yield curves by 100 and 160 bps, respectively, and was similar to the movement in the medium-term yields during the Asian crisis. $^{8}$ The second shock assumed a tilt of the U.S. dollar, indexed-unit, and peso yield curves, where short-term rates would increase more than longer-term rates as during the

\footnotetext{
${ }^{6}$ Data on the U.S. dollar, peso, and indexed-unit yield curves in Uruguay were obtained from BEVSA. See Guillermo Mara, 2005, "Curva Uruguay en Dólares de la Bolsa Electrónica de Valores del Uruguay: CUDBEVSA" (unpublished; Montevideo: BEVSA) for details on how the U.S. dollar yield curve is estimated.

${ }^{7} \mathrm{BROU}$ is excluded from this exercise as it does not report cash flows on the basis of their residual maturity.

${ }^{8}$ The shift in the U.S. dollar yield curve to a level similar to the one observed during the Asian, Brazilian, and Russian crises was based on Frache, Serafín, and Gabriel Katz, 2004, "Estimating a Risky Term-Structure of Uruguayan Sovereign Bonds" (unpublished; Montevideo: Universidad de la República).
} 
Brazilian crisis. Finally, the last shock was a shift of the yield curves to a level similar to the one observed during the Russian crisis.

Table 5. Uruguay: Interest Rate Shocks Applied to the U.S. Dollar, Peso, and Indexed-Unit Yield Curves 1/

(In basis points)

\begin{tabular}{lcc}
\multicolumn{3}{c}{ Peso Rates 2/ } \\
\hline Short & Medium & Long \\
Term & Term & Term
\end{tabular}

\begin{tabular}{lcc}
\multicolumn{3}{c}{ U.S. Dollar Rates 3/ } \\
\hline Short & Medium & Long \\
Term & Term & Term
\end{tabular}

\begin{tabular}{|c|c|c|c|c|c|c|}
\hline Tilt + & 160 & 110 & 90 & 100 & 50 & 30 \\
\hline Parallel + & 160 & 160 & 160 & 100 & 100 & 100 \\
\hline Russian crisis 4/ 5/ & 867 & 240 & 123 & 881 & 243 & -163 \\
\hline \multicolumn{7}{|l|}{ Memorandum items: } \\
\hline Brazilian crisis 4/ & n.a. & n.a. & n.a. & 80 & 30 & 0 \\
\hline Asian crisis 4/ & n.a. & n.a. & n.a. & 270 & 100 & 20 \\
\hline
\end{tabular}

1/ Short-term is defined as less than or equal to 3 months, medium-term is defined as greater than 3 months and less than or equal to 5 years, and long term is defined as greater than 5 years.

$2 /$ Shifts in the peso and indexed-unit yield curves.

3 / Shifts in the U.S. dollar-denominated domestic and foreign yield curves.

4/ Based on Serafín Frache, and Gabriel Katz, 2004, "Estimating a Risky Term Structure of Uruguayan

Sovereign Bonds," (unpublished manuscript; Montevideo: Universidad de la República).

5/ In the case of the Russian crisis, yield rates were calibrated so that the U.S. dollar 30-year long-term yield would shift by 163 bps while the 10 -year index-unit yield would shift by 123 bps.

81. The sensitivity of the banking system to a deterioration in the credit quality was estimated. One test examined the changes in a bank's required provisioning if the ratings of its debtors were replaced by the worst rating assigned to those debtors by any bank in the banking system. Banks with lax debtor ratings and/or deficient credit evaluation would require higher provisions. The provisioning shortfall would cause a reduction in capital, affecting the capital adequacy ratio.

82. The second credit risk stress test applied to the banking book was an increase of 60 percent in the probability of default (PD). This test is based on the calculation of a simplified value-at-risk (VaR) over a period of one year at a five percent confidence level using the Herfindahl-Hirschman concentration index, a normal probability distribution for loan losses, and the same probability of default for all debtors in a bank. ${ }^{9}$ This is equivalent to assuming that there exists only name concentration and no sectoral concentration in banks' loan portfolios. Even though the stress test derived under these assumptions underestimates risks in banks specializing in one sector, industry, or region, the results should be interpreted as the minimum credit losses the banking system can incur when the PD increases by a 60 percent. Expected credit losses (proportional to the mean of the loss distribution) are reflected in a shortfall of provisions and, thus, reduce capital. Furthermore, capital is also

\footnotetext{
${ }^{9}$ See Javier Márquez Diez-Canedo, 2005, “A Simplified Credit Risk Model for Supervisory Purposes in Emerging Markets,” BIS Paper No. 22 (Basel: Bank of International Settlements).
} 
affected by the increase in unexpected credit losses (proportional to the standard deviation of the loss distribution) under the different scenarios.

\section{All the parameters necessary for the credit risk model were obtained using} information from the public credit registry. For the calculation of expected losses, the BCU assumed that: (a) a loss given default (LGD) is equal to one hundred percent if loans are unsecured and to a smaller percentage based on the type of collateral and its liquidity if loans are secured; ${ }^{10}$ (b) the exposure at default is equal to the size of the loan portfolio, which also includes credit card lines; and (c) the probability of default (PD) was proxied by the empirical default rates (with a minimum rate equal to 4.5 percent) given that there is no information on the PDs for Uruguayan debtors.

\section{Macro scenario analysis}

84. The macro scenario analysis measures the impact on banks' capital and liquidity of three extreme but plausible scenarios in which simultaneous changes in several risk factors occur. The following three scenarios were defined in consultation with the BCU: a domestic supply shock, a current account shock, and a capital account shock (Table 6).

\section{Table 6. Macro Scenarios}

\begin{tabular}{|c|}
\hline \multirow[b]{2}{*}{$\begin{array}{l}\text { Domestic Supply Shock: Drought } \\
\text { A severe drought leads to a decline in agricultural output and exports, and disrupts hydroelectric power supply, } \\
\text { requiring intense use of thermoelectric generators. As a result, oil imports increase and the current account } \\
\text { balance declines. While inflation pressure picks up, monetary policy adjusts to keep inflation within the 5-7 } \\
\text { percent target range. The peso depreciates in line with inflation, with no changes in the real exchange rate. The } \\
\text { GDP falls by } 1 \text { percent below the baseline and agribusiness earnings weaken. }\end{array}$} \\
\hline \\
\hline Current Account Shock: Regional Contagion under Adverse Terms of Trade \\
\hline $\begin{array}{l}\text { Under this contagion scenario, Argentine private consumption declines by } 10 \text { percent, the Argentine peso } \\
\text { depreciates in nominal ( } 45 \text { percent) and real terms ( } 30 \text { percent), and the Brazilian real depreciates by } 10 \text { percent } \\
\text { in real terms. This takes place under adverse terms of trade, which worsen by } 4 \text { percent. Market confidence in } \\
\text { the region declines and sovereign spreads increase by } 500-550 \text { basis points. The government reacts by reducing } \\
\text { real government spending by } 2.5 \text { percent. GDP in Uruguay falls by } 4 \text { percent below the baseline, and the real } \\
\text { exchange rate depreciates by } 5 \text { percent. The central bank adjusts monetary policy to keep inflation within the } \\
\text { target range. }\end{array}$ \\
\hline Capital Account Shock: Capital Outflows under World Recession \\
\hline $\begin{array}{l}\text { A global "hard landing" scenario which leads to a sharp increase in international interest rates, capital flows out } \\
\text { of emerging markets triggering an increase in emerging market spreads ( } 600 \text { basis points). World output } \\
\text { declines and commodity prices collapse. Uruguayan peso depreciates by } 48 \text { percent in nominal ( } 12 \text { percent in } \\
\text { real) terms increasing public debt burden. The authorities partly accommodate the shocks through an increase in } \\
\text { the price level, which rises by } 15 \text { percent. GDP falls by } 8 \text { percent. }\end{array}$ \\
\hline
\end{tabular}

\footnotetext{
${ }^{10}$ For mortgage loans, collateral was assumed to be recovered only at 70 percent of its initial value.
} 
85. A macroeconometric model simulated the joint changes in the nominal and real exchange rates, tradable and nontradable price indices, country risk, and real GDP under the three scenarios described above. The BCU's macroeconometric model is a 22-equation structural model covering both real and nominal variables of the Uruguayan economy. Based on quarterly data, the model has two main blocks: (i) the real sector, which includes behavioral equations for the external sector, output, labor market, and real exchange rate; and (ii) the monetary sector, which incorporates inflation forecasts. Even though the model does not include an equation for the sovereign risk premium, the risk premium for each macro scenario was assigned according to similar historical episodes. The nominal exchange rate was also determined by the sum of inflation and real exchange rate forecasts. Table 7 below summarizes the changes in the main risk factors for each scenario obtained from the model.

Table 7. Uruguay: Inputs for the Stress Tests under a Domestic Supply Shock (Scenario 1), a Current Account Shock (Scenario 2), and a Capital Account Shock (Scenario 3)

(Percent change, unless otherwise indicated)

Risk Factor

Real exchange rate

Foreign prices

Domestic prices

Nominal exchange rate

GDP 1/

Country risk (in basis points) $2 /$

Source: BCU staff calculations.

$1 /$ GDP gap where long-term GDP growth is equal to 3 percent.

$2 /$ The country risk was calibrated according to similar historical episodes.

$\begin{array}{cc}\text { Scenario } 2 & \text { Scenario } 3 \\ 5 & 12 \\ -5 & -13 \\ 5 \text { to } 7 & 15 \\ 17 & 48 \\ -4 & -8\end{array}$

500 to $550 \quad$ Greater than 600

86. To quantify the impact of a scenario on the banks' capital adequacy each risk factor was estimated individually. The exchange rate risk component of the scenario analysis was a stress test on banks' net open position similar to the sensitivity test. For the interest rate risk component, BCU only focused on the effect of a parallel shift in the yield curves on banks' trading book. The credit risk component of the scenario analysis relied on the simplified version of the Mexican credit risk model where the PDs were stressed according to the different scenarios. ${ }^{11}$

\section{In the macro scenario analysis, the liquidity stress tests were also scenario-} driven. To obtain the effect of deposit withdrawals on the liquidity ratio, the BCU classified bank deposits into categories based on their estimated probability of being withdrawn and identified sources of funds that could become illiquid under tight market conditions. The tests assumed that changes in deposits would be driven by banks' fundamentals as well as by changes in the exchange rate and country risk.

\footnotetext{
${ }^{11}$ See Javier Márquez Diez-Canedo, 2005, “A Simplified Credit Risk Model for Supervising Purposes in Emerging Markets,” BIS Paper No. 22, Part 18 (April).
} 


\section{SUMMARY OF KEY RECOMMENDATIONS TO STRENGTHEN THE AML/CFT REGIME}

- $\quad$ Develop, as planned, a coordinated national AML/CFT strategy to be implemented in 2006.

- $\quad$ Improve CFT legislation and the regulatory framework for all FIs.

- $\quad$ Cover missing elements of the designated non-financial businesses and professions sectors in the AML/CFT legislation and prioritize implementation in the company services and casino sectors.

- $\quad$ Strengthen and enforce customer due diligence (CDD) requirements in all sectors, and give priority to CDD for offshore/cross-border business and legal entities (e.g., beneficial ownership and control of companies).

- $\quad$ Enhance and expand AML/CFT supervision in all sectors, particularly on-site inspections of nonbank and offshore institutions.

- $\quad$ Establish formal cooperation and information exchange mechanisms with other overseas supervisors that include AML/CFT elements (e.g., Argentina, Brazil, and Paraguay).

- $\quad$ Raise ML/FT risk awareness in all areas particularly for higher-risk sectors.

- Improve the registration system for legal entities, real estate, and other property.

- $\quad$ Strengthen control mechanisms in key sectors (e.g., public sector casinos).

- Improve the efficiency and resources of the judiciary, prosecution, and law enforcement agencies.

- $\quad$ Enhance capacity and resources in the financial intelligence unit and the BCU's supervisory units. 
Table 8. Uruguay: Banking System Asset and Liability Structure, 2000-05 (In percent of total assets)

\begin{tabular}{|c|c|c|c|c|c|c|}
\hline & 2000 & 2001 & 2002 & 2003 & 2004 & Jun-05 \\
\hline Total assets & 100.0 & 100.0 & 100.0 & 100.0 & 100.0 & 100.0 \\
\hline Liquid assets & 5.5 & 7.8 & 7.9 & 11.3 & 10.5 & 11.9 \\
\hline Securitities & 6.2 & 5.6 & 5.4 & 8.1 & 10.7 & 9.9 \\
\hline Net Credit & 79.7 & 78.6 & 78.8 & 72.9 & 70.2 & 69.5 \\
\hline Performing & 69.3 & 66.9 & 57.1 & 62.1 & 63.7 & 63.2 \\
\hline Financial sector & 24.3 & 25.1 & 26.6 & 36.3 & 36.4 & 37.3 \\
\hline $\mathrm{BCU}$ & 6.2 & 6.6 & 8.4 & 16.5 & 13.7 & 15.7 \\
\hline Domestic institutions & 1.1 & 0.8 & 7.1 & 5.6 & 4.7 & 4.4 \\
\hline Foreign institutions & 17.0 & 17.7 & 11.1 & 14.2 & 18.0 & 17.2 \\
\hline Public sector & 2.8 & 3.0 & 5.3 & 2.9 & 2.7 & 1.7 \\
\hline Private sector & 36.2 & 29.8 & 22.3 & 21.7 & 23.5 & 23.3 \\
\hline Nonresidents & 6.0 & 9.1 & 2.8 & 1.2 & 1.1 & 1.0 \\
\hline To be liquidated & 3.0 & 3.1 & 1.5 & 1.0 & 1.2 & 1.0 \\
\hline Nonperforming & 6.8 & 8.0 & 19.4 & 7.1 & 4.2 & 4.0 \\
\hline Other assets & 8.6 & 7.9 & 7.8 & 7.7 & 8.6 & 8.7 \\
\hline Total liabilities & 87.2 & 92.9 & 108.8 & 93.8 & 92.0 & 91.1 \\
\hline Deposits & 84.5 & 88.1 & 104.8 & 90.3 & 87.7 & 87.2 \\
\hline Financial sector & 12.1 & 10.7 & 27.6 & 12.0 & 7.9 & 7.1 \\
\hline \multicolumn{7}{|l|}{ Of which } \\
\hline Central Bank & 4.2 & 3.8 & 12.4 & 1.7 & 0.8 & 0.6 \\
\hline Public sector & 2.0 & 1.8 & 7.5 & 8.0 & 6.5 & 9.1 \\
\hline Private sector & 46.5 & 45.7 & 50.6 & 57.7 & 59.7 & 58.2 \\
\hline Nonresidents & 23.9 & 29.9 & 19.1 & 12.7 & 13.5 & 12.8 \\
\hline Other liabilities & 4.6 & 4.8 & 4.0 & 3.5 & 4.4 & 4.0 \\
\hline Net worth & 10.9 & 7.1 & -8.8 & 6.2 & 8.0 & 8.9 \\
\hline \multicolumn{7}{|l|}{ Memorandum item: } \\
\hline Total assets (in billions of U.S. dollars) & 20.2 & 21.1 & 12.3 & 11.6 & 11.9 & 12.4 \\
\hline
\end{tabular}

Source: Banco Central del Uruguay. 


\section{Table 9. Uruguay: Financial Soundness Indicators 1/}

\begin{tabular}{|c|c|c|c|c|c|c|}
\hline & 2001 & 2002 & 2003 & 2004 & Jun-05 & 2005 \\
\hline \multicolumn{7}{|l|}{ Capital adequacy indicators } \\
\hline Capital/assets (percent) & 7.3 & -8.8 & 6.2 & 8.0 & 8.9 & 8.0 \\
\hline \multicolumn{7}{|l|}{ Asset quality indicators } \\
\hline Nonperforming loans to total loans (percent) & 16.1 & 38.6 & 13.6 & 9.2 & 8.9 & 8.4 \\
\hline Loan provisions to nonperforming loans (percent) & 49.9 & 55.0 & 66.1 & 59.3 & 57.4 & 53.4 \\
\hline Loan provisions to total loans (percent) & 8.0 & 21.2 & 9.0 & 5.4 & 5.1 & 4.5 \\
\hline Credit growth (net of provisions, percent) & 21.5 & 7.1 & -6.6 & -10.7 & -3.8 & 4.7 \\
\hline Net credit to the nonfinancial sector to total assets (percent) & 42.0 & 46.1 & 25.4 & 27.3 & 26.0 & 25.7 \\
\hline \multicolumn{7}{|l|}{ Profitability indicators } \\
\hline ROA & -2.0 & -29.8 & -2.8 & 0.7 & 0.9 & 0.5 \\
\hline ROE & -27.4 & $\ldots$ & -44.7 & 9.2 & 10.3 & 6.5 \\
\hline Financial margin to gross income & -2.6 & 0.0 & -1.4 & 5.3 & 2.1 & 4.3 \\
\hline Noninterest expenses to gross income & -3.9 & -0.6 & -4.8 & 14.2 & 4.9 & 13.3 \\
\hline Personnel expenses to noninterest expenses & 32.6 & 14.7 & 16.2 & 17.7 & 22.4 & 16.4 \\
\hline Spread between lending and deposit rates (domestic currency, percent) & 27.0 & 55.8 & 29.3 & 17.5 & 10.8 & $\ldots$ \\
\hline Spread between lending and deposit rates (foreign currency, percent) & 6.3 & 7.6 & 7.9 & 6.3 & 5.1 & $\ldots$ \\
\hline \multicolumn{7}{|l|}{ Liquidity indicators } \\
\hline Liquid assets to total assets (percent) & 7.8 & 7.9 & 11.3 & 10.5 & 11.9 & $\ldots$ \\
\hline Liquid assets to total deposits (percent) & 8.9 & 7.6 & 12.5 & 12.0 & 13.7 & $\ldots$ \\
\hline Foreign currency assets to foreign currency deposits (percent) & 8.1 & 7.0 & 12.5 & 11.6 & 12.1 & $\ldots$ \\
\hline Domestic currency assets to domestic currency deposits (percent) & 16.3 & 14.5 & 12.1 & 14.3 & 22.1 & $\ldots$ \\
\hline Net loans to the private sector/total deposits (percent) & 47.8 & 29.1 & 28.5 & 31.1 & 29.8 & $\ldots$ \\
\hline Foreign currency loans to foreign currency deposits (percent) & 40.2 & 25.1 & 25.5 & 28.2 & 28.1 & $\ldots$ \\
\hline Domestic currency loans to domestic currency deposits (percent) & 115.8 & 79.1 & 51.1 & 48.2 & 38.6 & $\ldots$ \\
\hline
\end{tabular}

Sensitivity-to-risk indicators

Average maturity (years)

Private banks

Assets

Liabilities

Public banks

Assets

Liabilities

Cooperative banks

Assets

Liabilities

Net open position (percentage of net worth)

BROU, BHU, private banks and cooperatives

BROU, private banks, and cooperatives

Public banks

Private banks

Cooperative banks

$\begin{array}{rrrrrr}1.7 & 1.3 & 1.2 & 1.1 & 1.2 & \ldots \\ 1.0 & 1.7 & 1.0 & 0.7 & 0.6 & \ldots \\ & & & & & \\ 1.3 & 1.5 & 1.6 & 1.9 & 1.8 & \ldots \\ 0.5 & 1.3 & 0.9 & 0.3 & 0.3 & \ldots \\ & & & & & \\ 1.9 & 2.0 & 1.3 & 1.3 & 1.6 & \ldots \\ 1.3 & 1.2 & 0.8 & 0.7 & 1.1 & \ldots \\ -95.7 & 232.5 & -48.2 & -8.6 & -8.4 & \ldots \\ 2.1 & -12.8 & 3.4 & 5.0 & 4.8 & \ldots \\ -2.6 & -3.5 & -2.5 & -0.9 & -0.8 & \ldots \\ 0.4 & 1.1 & 0.7 & 0.6 & 0.6 & \ldots \\ 0.1 & 0.2 & 0.9 & 1.0 & 0.5 & \ldots \\ & & & & & \end{array}$

Sources: Banco Central del Uruguay; and staff estimates.

1/ Includes private and public banks (BROU and BHU) and cooperatives. 
Table 10. Uruguay: Selected Macroeconomic Indicators

\begin{tabular}{|c|c|c|c|c|}
\hline & 2002 & 2003 & 2004 & 2005 \\
\hline & \multicolumn{3}{|c|}{ (Percent change, unless otherwise indicated) } & \\
\hline & \multicolumn{3}{|c|}{ I. Output, prices, and employment } & \\
\hline Real GDP & -11.0 & 2.2 & 11.8 & 6.6 \\
\hline GDP (US\$ billions) & 12.1 & 11.2 & 13.3 & 16.9 \\
\hline GDP deflator & 18.7 & 18.4 & 7.5 & 1.7 \\
\hline CPI inflation (eop) & 25.9 & 10.2 & 7.6 & 4.9 \\
\hline Exchange rate change (Ur\$/US\$) (eop) & 84.2 & 7.3 & -9.9 & -8.3 \\
\hline Average public sector wage (end-of-period) & 0.5 & 7.9 & 9.7 & 10.2 \\
\hline \multirow[t]{2}{*}{ Unemployement (in percent) } & 17.0 & 16.9 & 13.1 & 12.1 \\
\hline & \multicolumn{3}{|c|}{ II. Monetary indicators } & \\
\hline Base Money $1 /$ & 22.1 & 24.9 & 11.1 & 34.1 \\
\hline M1 & 1.7 & 34.6 & 13.4 & 29.4 \\
\hline M3 & 15.8 & 21.7 & -2.0 & 0.1 \\
\hline \multirow[t]{3}{*}{ Credit to the private sector (constant exch. rate) $2 /$} & -17.6 & -23.9 & -11.2 & 2.7 \\
\hline & \multicolumn{3}{|c|}{ (Percent of GDP, unless otherwise indicated) } & \\
\hline & \multicolumn{3}{|c|}{ III. Public sector operations } & \\
\hline Revenue & 32.1 & 32.0 & 30.9 & 31.8 \\
\hline Non-interest expenditure (incl. discrepancy) & 32.1 & 29.3 & 27.2 & 27.9 \\
\hline Primary balance & 0.0 & 2.7 & 3.8 & 3.9 \\
\hline Interest & 4.7 & 6.0 & 6.0 & 4.6 \\
\hline Overall balance & -4.6 & -3.2 & -2.2 & -0.7 \\
\hline Public sector debt $3 /$ & 96 & 104 & 92 & 69 \\
\hline \multirow[t]{2}{*}{ Public debt service (as a percent of GDP) } & 13 & 14 & 19 & 16 \\
\hline & \multicolumn{3}{|c|}{ IV. Savings and investment } & \\
\hline Gross domestic investment & 11.5 & 12.6 & 13.3 & 13.2 \\
\hline Gross national savings & 14.7 & 12.1 & 13.6 & 12.6 \\
\hline \multirow[t]{2}{*}{ Foreign savings } & -3.2 & 0.5 & -0.3 & 0.5 \\
\hline & \multicolumn{3}{|c|}{ V. External indicators } & \\
\hline Merchandise exports, fob (US\$ millions) & 1,922 & 2,281 & 3,145 & 3,758 \\
\hline Merchandise imports, fob (US\$ millions) & 1,874 & 2,098 & 2,992 & 3,826 \\
\hline Merchandise terms of trade (percentage change) & 4.3 & 2.9 & -3.1 & -9.7 \\
\hline Current account balance & 3.2 & -0.5 & 0.3 & -0.5 \\
\hline Of which: Excluding cellulose projects & 3.2 & -0.5 & 0.3 & 0.1 \\
\hline Foreign direct investment & 1.5 & 3.6 & 2.4 & 3.6 \\
\hline Overall balance of payments (US\$ millions) & $-2,328$ & 1,380 & 454 & 951 \\
\hline External debt 4/ & 87.5 & 98.2 & 87.4 & 67.8 \\
\hline External debt service (percent of exports of goods and services) & 55.0 & 52.3 & 44.8 & 47.0 \\
\hline Gross official reserves (US\$ millions) 5/ & 772 & 2,087 & 2,512 & 3,438 \\
\hline In months of imports of goods and services & 3.7 & 9.2 & 8.0 & 8.7 \\
\hline In percent of short-term debt plus FX deposits & 7.0 & 20.0 & 27.7 & 32.9 \\
\hline REER (percentage depreciation -, e.o.p.) & -20.3 & -13.2 & 9.3 & 11.9 \\
\hline
\end{tabular}

Sources: Data provided by the Uruguayan authorities; and Fund staff estimates.

1/ Program definition (end of period data).

2/ Part of the sharp drop in 2003 is due to the removal of the three liquidated banks from the database in May 2003.

3/ Covers debt of the NFPS and the central bank (excluding monetary policy instruments and free reserves).

4/ Excludes nonresident deposits.

5/ Includes reserve buildup through reserve requirements of resident financial institutions. 
Table 11. Uruguay. Financial Integration and Net Foreign Assets, 2001-04

\begin{tabular}{lrrrrrrrr}
\hline & \multicolumn{3}{c}{ Financial Integration 1/ } & \multicolumn{3}{c}{ Net Foreign Assets 2/ } \\
\hline & 2001 & 2002 & 2003 & 2004 & 2001 & 2002 & 2003 & 2004 \\
\hline Argentina & 126 & 310 & 246 & 224 & -45 & -72 & -56 & -48 \\
Brazil & 102 & 108 & 115 & 106 & -51 & -50 & -56 & -49 \\
Chile & 199 & 204 & 229 & 199 & -41 & -39 & -47 & -37 \\
Colombia & 105 & 105 & 114 & 107 & -30 & -33 & -37 & -35 \\
Mexico & 78 & 75 & 80 & 84 & -37 & -37 & -41 & -43 \\
Uruguay & $\mathbf{1 9 4}$ & $\mathbf{1 9 3}$ & $\mathbf{2 8 0}$ & $\mathbf{2 8 6}$ & $\mathbf{- 1 0}$ & $\mathbf{- 1 1}$ & $\mathbf{- 1 3}$ & $\mathbf{- 2 3}$ \\
Czech Republic & 151 & 160 & 155 & 163 & -11 & -18 & -23 & -35 \\
Hungary & 158 & 151 & 163 & 181 & -69 & -76 & -84 & -97 \\
Thailand & 145 & 132 & 128 & 119 & -50 & -39 & -38 & -29 \\
Indonesia & 133 & 115 & 103 & 101 & -71 & -57 & -50 & -52 \\
& & & & & & & &
\end{tabular}

Source: Philip R. Lane and Gian Maria Milesi-Ferretti, "The External Wealth of Nations Mark II: Revised and Extended Estimates of Foreign Assets and Liabilities, 1970-2004," IMF Working Paper, forthcoming.

1/ Measured as total foreign assets plus liabilities in percent of GDP.

2/ Measured as total foreign assets less total foreign liabilities in percent of GDP. 


\section{Table 12. Regulations that Discriminate by Currency Composition}

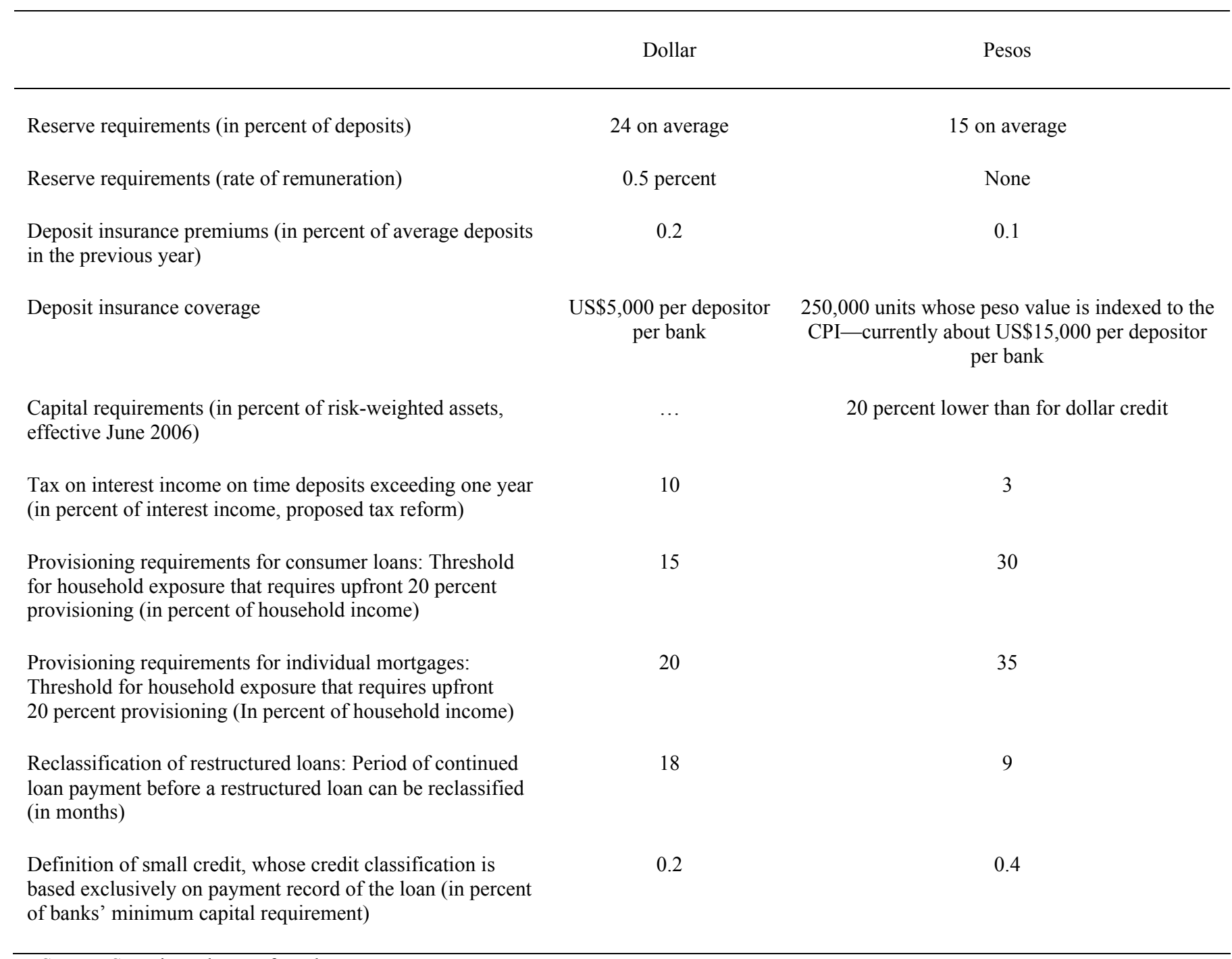




\section{Table 13. Share of Foreign Currency Credit to the Nontradable Sector in Total Credit 1/ (In percent)}

Banking System
Banks 2/
Mean (simple average)
Maximum
Minimum
Standard deviation
Finance Houses 2/
Mean (simple average)
Maximum
Minimum
Standard deviation

Cooperatives 2/
Mean (simple average)
Maximum
Minimum
Standard deviation
Source: Superintendency of Banks.
1/ Tradable sector proxied by agriculture and industry.
2/ Weighted average.

$\begin{array}{rrr}\mathbf{4 5 . 9} & \mathbf{3 4 . 3} & \mathbf{3 0 . 7} \\ \mathbf{4 4 . 9} & \mathbf{3 2 . 7} & \mathbf{2 9 . 7} \\ 49.1 & 38.7 & 36.0 \\ 66.5 & 56.9 & 57.9 \\ 19.0 & 14.7 & 13.0 \\ 15.0 & 12.6 & 12.5 \\ & & \\ \mathbf{4 4 . 9} & \mathbf{3 2 . 7} & \mathbf{2 9 . 7} \\ 40.2 & 34.5 & 34.4 \\ 76.5 & 76.1 & 51.9 \\ 5.3 & 2.8 & 7.4 \\ 26.7 & 25.3 & 17.6 \\ & & \\ \mathbf{3 6 . 4} & \mathbf{3 1 . 8} & \mathbf{3 4 . 2} \\ 57.5 & 48.8 & 34.5 \\ 78.1 & 64.3 & 51.3 \\ 21.8 & 13.5 & 4.3 \\ 25.3 & 24.0 & 26.2\end{array}$

30.7

29.7

57.9

13.0

12.5

29.7

34.4

51.9

7.4

17.6

34.2

34.5

51.3

26.2

\section{Table 14. Financial Sector Taxes}

Profit tax (IRIC) 1/2/

Net worth tax (IPAT)

Value-added tax 3/

Asset tax (IMABA) 1/

Supervisory tax (ICOSIFI)

Credit card tax 1/

Supervisory fee $4 /$
30 percent of profits

2.8 percent of taxable net worth

23 percent of interest on loans to individuals

2 percent of assets

0.10 percent of assets

0.10 UR (wage-indexed units) per credit card issued

0.10 percent of assets

Source: Uruguayan authorities.

1/ Envisaged to be eliminated in the tax reform submitted to congress in March 2006.

$2 /$ Replaced by a simplified corporate income tax with a rate of 25 percent of profits.

3 / Envisaged to be reduced to 22 percent in the tax reform submitted to congress.

4/ Envisaged to be introduced in the tax reform submitted to congress in December 2005. 
Table 15. Liabilities of Nonfinancial Corporate Sector Denominated or Indexed to Foreign Currency

(Median Values, in percent of total liabilities)

\begin{tabular}{|c|c|c|c|c|c|c|}
\hline & 1999 & 2000 & 2001 & 2002 & 2003 & 2004 \\
\hline Uruguay & 85.4 & 88.0 & 74.0 & n.a. & 82.1 & 74.1 \\
\hline Bolivia & 69 & 77 & 84 & 73 & 75 & 71 \\
\hline Peru & 68.0 & 63.2 & 62.9 & 61.4 & 61.2 & 57.9 \\
\hline Argentina & 64.8 & 64.7 & 67.9 & 68.9 & 58.8 & 54.9 \\
\hline Mexico & 42.9 & 37.6 & 30.0 & 35.7 & 17.9 & 17.3 \\
\hline Brazil & 11.7 & 17.7 & 20.2 & 16.5 & 13.1 & 12.7 \\
\hline Colombia & 0.6 & 0.2 & 0.5 & 0.1 & 0.1 & 0.3 \\
\hline Chile & 5.1 & 1.0 & 1.7 & 2.1 & 1.1 & 0.0 \\
\hline
\end{tabular}


Table 16. Comparative Pension Commissions, 2004 1/

\begin{tabular}{lcc}
\hline & As Percent of Salary & $\begin{array}{c}\text { As Percent of the Sum } \\
\text { of Capitalized } \\
\text { Amount plus } \\
\text { Commission }\end{array}$ \\
\hline Argentina & 1.10 & 20.10 \\
Bolivia & 0.50 & 4.80 \\
Chile & 1.51 & 13.10 \\
Colombia & 1.55 & 13.40 \\
El Salvador & 1.71 & 14.50 \\
Mexico & 1.46 & 17.20 \\
Peru & 2.27 & 22.10 \\
Dominican Republic & 0.50 & 8.30 \\
Uruguay 2/ & $\mathbf{1 . 8 0}$ & $\mathbf{1 3 . 9 0}$ \\
\hline Source: Asociación Internacional de Organismos de Supervisión de Fondos de \\
Pensiones. \\
1/ Life insurance premiums not included in figures. \\
2/ Data as of 6/30/05.
\end{tabular}

Table 17. Public Pension Fiscal Situation, 2002-04

\begin{tabular}{lrrr}
\hline & 2002 & 2003 & 2004 \\
\hline Expenditures & & & \\
In billion of Ur\$ & 38.5 & 40.0 & 42.6 \\
In percent of GDP & 14.7 & 12.7 & 11.2 \\
& & & \\
Contributions & & & \\
In billion of Ur\$ & 18.7 & 19.2 & 21.8 \\
In percent of GDP & 7.2 & 6.1 & 5.7 \\
& & & \\
Earmarked Taxes & & & \\
In billion of Ur\$ & 7.1 & 9.0 & 11.0 \\
In percent of GDP & 2.7 & 2.9 & 2.9 \\
& & & \\
Deficit & & & \\
In billion of Ur\$ & 12.4 & 11.6 & 9.9 \\
In percent of GDP & 4.7 & 3.7 & 2.6 \\
\hline$\quad$ Source: Banco de Previsión Social, 2005, Boletín Estadistico, \\
Número 60.
\end{tabular}


Table 18. Pension Fund Industry Concentration, 2004

\begin{tabular}{lcc}
\hline \multicolumn{1}{c}{ Country } & Number of AFP/AFAPs & $\begin{array}{c}\text { Share of Two Largest } \\
\text { (In percent) }\end{array}$ \\
\hline Argentina & 12 & 39.8 \\
Bolivia & 2 & 100.0 \\
Chile & 6 & 55.3 \\
Colombia & 6 & 51.2 \\
Costa Rica & 8 & 63.5 \\
El Salvador & 2 & 100.0 \\
Mexico & 13 & 42.2 \\
Peru & 4 & 58.6 \\
Dominican Republic & 8 & 53.2 \\
Uruguay & 4 & 74.4 \\
Average & 7.2 & 50.9 \\
\hline
\end{tabular}

Source: Asociación Internacional de Organismos de Supervisión de Fondos de Pensiones.

Table 19. Composition of Invested Pension Funds

(In percent share)

\begin{tabular}{lcccrrrrr}
\hline & $\begin{array}{c}\text { Government } \\
\text { Debt }\end{array}$ & $\begin{array}{c}\text { Financial } \\
\text { Institutions }\end{array}$ & $\begin{array}{c}\text { Nonfinancial } \\
\text { Institutions }\end{array}$ & Stocks & $\begin{array}{c}\text { Mutual } \\
\text { Funds }\end{array}$ & $\begin{array}{c}\text { Foreign } \\
\text { Securities }\end{array}$ & $\begin{array}{c}\text { Total Assets } \\
\text { Others } \\
\text { (In billions } \\
\text { of U.S. } \\
\text { dollars) }\end{array}$ \\
\hline Argentina & 62.0 & 6.6 & 2.0 & 12.7 & 4.8 & 10.3 & 1.7 & 18.3 \\
Bolivia & 67.5 & 5.6 & 16.9 & 7.5 & 3.1 & 1.5 & 1.1 & 1.7 \\
Chile & 18.7 & 28.5 & 7.1 & 15.7 & 2.2 & 26.8 & 0.2 & 60.8 \\
Colombia & 48.5 & 16.6 & 19.6 & 6.2 & $\ldots$ & 6.7 & 0.1 & 11.1 \\
El Salvador & 83.5 & 10.5 & 5.8 & 0.2 & $\ldots$ & $\ldots$ & $\ldots$ & 2.1 \\
Mexico & 85.5 & 4.9 & 9.6 & $\ldots$ & 1.4 & $\ldots$ & $\ldots$ & 42.5 \\
Peru & 24.2 & 11.4 & 11.5 & 37.7 & $\ldots$ & 10.2 & 3.4 & 7.8 \\
Dominican Rep. & 32.5 & 61.8 & 0.7 & 3.8 & $\ldots$ & $\ldots$ & 1.3 & $\ldots .5$ \\
Uruguay 1/ & $\mathbf{8 0 . 0}$ & $\mathbf{1 5 . 0}$ & $\mathbf{4 . 2}$ & $\ldots$ & $\ldots$ & $\ldots$ & $\mathbf{1 . 0}$ \\
\hline
\end{tabular}

Source: AIOS, BCU. Data as of 12/31/04.

1/ Central Bank for Uruguay included under government debt. 
Table 20. Insurance Sector: Some Comparative Statistics, 2003 1/

\begin{tabular}{|c|c|c|c|c|c|c|c|c|c|c|}
\hline \multirow[t]{3}{*}{ Country } & \multirow{2}{*}{\multicolumn{2}{|c|}{$\begin{array}{l}\text { Insurance } \\
\text { Penetration }\end{array}$}} & \multirow{2}{*}{\multicolumn{2}{|c|}{$\begin{array}{l}\text { Insurance } \\
\text { Density }\end{array}$}} & \multirow{2}{*}{\multicolumn{2}{|c|}{$\begin{array}{c}\text { Proportion } \\
\text { of Total }\end{array}$}} & \multicolumn{4}{|c|}{ Rates of Change (periods to 2003) } \\
\hline & & & & & & & \multicolumn{2}{|c|}{ Penetration (real) } & \multicolumn{2}{|c|}{ Density } \\
\hline & In percent & Rank & $\begin{array}{l}\text { In U.S. } \\
\text { dollars }\end{array}$ & Rank & In percent & Rank & 3 years & 5 years & 3 years & 5 years \\
\hline \multicolumn{11}{|l|}{ Life Insurance } \\
\hline Uruguay & 0.48 & 63 & 15.4 & 58 & 22 & 69 & 12.2 & -5.9 & -10.9 & -17.9 \\
\hline Argentina & 0.72 & 55 & 24.2 & 54 & 28 & 58 & -8.5 & 0.6 & -30.4 & -15.9 \\
\hline Brazil & 1.28 & 43 & 35.8 & 50 & 43 & 41 & 52.6 & 26.8 & 40.5 & 14.1 \\
\hline Mexico & 0.70 & 57 & 41.3 & 48 & 39 & 48 & -6.6 & 0.3 & -6.7 & 7.8 \\
\hline Chile & 2.61 & 29 & 138.3 & 37 & 64 & 19 & -3.7 & 3.2 & 3.2 & 5.3 \\
\hline Peru & 0.60 & 61 & 13.5 & 60 & 42 & 45 & 16.4 & 19.1 & 19.6 & 16.1 \\
\hline Panama & 1.19 & 46 & 42.4 & 47 & 33 & 55 & -8.4 & 4.4 & 2.1 & 5.7 \\
\hline Costa Rica & 0.17 & 77 & 7.0 & 67 & 9 & 78 & 0.0 & -1.1 & -0.5 & 5.7 \\
\hline Dominican Republic & 0.20 & 75 & 3.7 & 76 & 8 & 81 & -1.6 & -2.8 & -8.3 & -1.5 \\
\hline \multicolumn{11}{|l|}{ Nonlife Insurance } \\
\hline Uruguay & 1.68 & 56 & 54.5 & 57 & 78 & 20 & 2.3 & 7.5 & -18.1 & -6.0 \\
\hline Argentina & 1.82 & 50 & 61.7 & 55 & 72 & 31 & 5.5 & 5.5 & -19.8 & -11.7 \\
\hline Brazil & 1.68 & 56 & 46.8 & 58 & 57 & 48 & -1.4 & -1.0 & -9.3 & -11.2 \\
\hline Mexico & 1.10 & 70 & 65.3 & 53 & 61 & 41 & 9.0 & 5.8 & 9.0 & 13.6 \\
\hline Chile & 1.47 & 64 & 78.0 & 50 & 36 & 70 & 8.5 & 5.0 & 16.2 & 7.2 \\
\hline Peru & 0.83 & 76 & 18.7 & 74 & 58 & 44 & 8.5 & 5.0 & 10.9 & 2.0 \\
\hline Panama & 2.45 & 31 & 87.3 & 44 & 67 & 34 & -10.9 & -1.4 & -0.6 & -0.1 \\
\hline Costa Rica & 1.72 & 54 & 72.0 & 52 & 91 & 11 & -3.3 & -4.5 & -4.0 & 2.5 \\
\hline Dominican Republic & 2.23 & 34 & 42.0 & 60 & 92 & 8 & 7.2 & 8.8 & -0.3 & 10.9 \\
\hline \multicolumn{11}{|l|}{ Total } \\
\hline Uruguay & 2.16 & 62 & 69.9 & 59 & n.a. & n.a. & 4.2 & 3.5 & -16.7 & -9.6 \\
\hline Argentina & 2.54 & 57 & 85.9 & 53 & n.a. & n.a. & 0.7 & 4.0 & -23.4 & -13.0 \\
\hline Brazil & 2.96 & 51 & 82.6 & 55 & n.a. & n.a. & 11.9 & 6.5 & 3.0 & -4.4 \\
\hline Mexico & 1.80 & 68 & 106.6 & 49 & n.a. & n.a. & 1.7 & 3.4 & 1.7 & 11.1 \\
\hline Chile & 4.08 & 39 & 216.3 & 40 & n.a. & n.a. & 0.1 & 3.8 & 7.2 & 6.0 \\
\hline Peru & 1.43 & 75 & 32.2 & 75 & n.a. & n.a. & 11.6 & 9.7 & 14.2 & 6.7 \\
\hline Panama & 3.64 & 40 & 129.7 & 47 & n.a. & n.a. & -10.1 & 0.3 & 0.3 & 1.6 \\
\hline Costa Rica & 1.89 & 66 & 79.0 & 57 & n.a. & n.a. & -3.0 & -4.2 & -3.7 & 2.8 \\
\hline Dominican Republic & 2.43 & 58 & 45.7 & 64 & n.a. & n.a. & 6.4 & 7.5 & -1.1 & 9.5 \\
\hline
\end{tabular}

Source: Swiss Re Sigma, Staff Analysis.

1/ Rankings shown are comparative to the 92 jurisdictions in the Swiss Re study. 
Table 21. Chronology of Changes in Selected Prudential Regulations, 2002-05

\begin{tabular}{|c|c|c|}
\hline Date & Classification & Description \\
\hline $\begin{array}{l}\text { Feb 28, } 2002 \\
\text { (Circular 1.773) }\end{array}$ & Risk rating & $\begin{array}{l}\text { All banks and cooperatives are required to present to the } \\
\text { supervisor a report from an independent rating agency at } \\
\text { least once a year. Banks are allowed to use the rating scale } \\
\text { of another entity (including a parent bank) if this entity fully } \\
\text { guarantees the deposits in the conditions in which they were } \\
\text { contracted. Rating agencies are to use the local rating scale, } \\
\text { in addition to their own. }\end{array}$ \\
\hline $\begin{array}{l}\text { Mar 22, } 2002 \\
\text { (Circular 1.778) }\end{array}$ & Fit and proper & $\begin{array}{l}\text { Establishes guidelines for the formation of the supervisory } \\
\text { opinion necessary for the operation of new financial } \\
\text { institutions, including information requirements from } \\
\text { shareholders and senior management of financial } \\
\text { institutions. }\end{array}$ \\
\hline $\begin{array}{l}\text { Dec 20, } 2002 \\
\text { (Comunicación } \\
\text { 2002/225) }\end{array}$ & $\begin{array}{l}\text { Accounting } \\
\text { standards }\end{array}$ & $\begin{array}{l}\text { Modifies the accounting plan on the treatment of investment } \\
\text { assets, distinguishing between those for trading and those } \\
\text { held to maturity, following NIC principles. Tradable } \\
\text { securities are to be valued at market prices. }\end{array}$ \\
\hline $\begin{array}{l}\text { Jan } 2,2003 \\
\text { (Circular } 1.837)\end{array}$ & $\begin{array}{l}\text { Capital } \\
\text { requirements }\end{array}$ & Sharply increases minimum capital requirements. \\
\hline $\begin{array}{l}\text { Feb 20, } 2003 \\
\text { (Circular 1.842) }\end{array}$ & Credit bureau & $\begin{array}{l}\text { Increases from quarterly to monthly the frequency of } \\
\text { information submitted to the credit bureau. }\end{array}$ \\
\hline $\begin{array}{l}\text { Apr 2, } 2003 \\
\text { (Circular 1.850) }\end{array}$ & $\begin{array}{l}\text { Nonresident } \\
\text { deposits }\end{array}$ & $\begin{array}{l}\text { Imposes a liquidity requirement equivalent to } 30 \text { percent of } \\
\text { non less than one year maturity nonresident nonfinancial } \\
\text { sector deposits and other obligations, to be held in selected } \\
\text { asset classes. }\end{array}$ \\
\hline $\begin{array}{l}\text { Sep 12, } 2003 \\
\text { (Comunicación } \\
\text { 2003/179) }\end{array}$ & $\begin{array}{l}\text { Information } \\
\text { technology }\end{array}$ & $\begin{array}{l}\text { Requires banks to adopt management practices guided by } \\
\text { the Control Objectives for Information and Related } \\
\text { Technology (COBIT) framework issued by the Information } \\
\text { Systems Audit and Control Foundation (ISACF). }\end{array}$ \\
\hline $\begin{array}{l}\text { Sep } 15,2003 \\
\text { (Comunicación } \\
2003 / 180 \text { ) }\end{array}$ & $\begin{array}{l}\text { Credit } \\
\text { classification }\end{array}$ & $\begin{array}{l}\text { Requires financial institutions to write off past due loans } \\
\text { from financial institutions. Nonfinancial sector borrowers } \\
\text { with past due loans for more than } 240 \text { days (morosos) in one } \\
\text { institution must be provisioned in all institutions (arrastre), } \\
\text { with a credit classification of } 3 \text {. Improvements in credit } \\
\text { classification can be done at any time to be symmetric with } \\
\text { deteriorations in classification. }\end{array}$ \\
\hline $\begin{array}{l}\text { Oct } 2,2003 \\
\text { (Circular 1.877) }\end{array}$ & Prudential limits & $\begin{array}{l}\text { Reduces regulatory limits on exposures to the nonfinancial } \\
\text { sector, the foreign public sector and related entities. } \\
\text { Establishes exposure limits on the financial sector, the } \\
\text { Uruguayan public sector, and country risk limits. }\end{array}$ \\
\hline $\begin{array}{l}\text { Oct } 2,2003 \\
\text { (Circular } 1.878)\end{array}$ & $\begin{array}{l}\text { Information } \\
\text { technology }\end{array}$ & $\begin{array}{l}\text { Banks must keep information available for the central bank } \\
\text { for a period of } 20 \text { years. }\end{array}$ \\
\hline $\begin{array}{l}\text { Oct } 2,2003 \\
(\text { Circular } 1.879)\end{array}$ & $\begin{array}{l}\text { Credit: Borrower } \\
\text { information }\end{array}$ & $\begin{array}{l}\text { Borrowers with credits exceeding } 5 \text { percent of basic capital } \\
\text { requirements need to present financial statements adjusted } \\
\text { by inflation. Those exceeding } 15 \text { percent must present the } \\
\text { audited statements as well. Imposes requirements that } \\
\text { borrowers must present on their external auditors. }\end{array}$ \\
\hline
\end{tabular}


Table 21. Chronology of Changes in Selected Prudential Regulations: 2002-05 (concluded)

\begin{tabular}{|c|c|c|}
\hline Date & Classification & Description \\
\hline $\begin{array}{l}\text { Nov 3, } 2003 \\
\text { (Comunicación } \\
\text { 2003/198) }\end{array}$ & $\begin{array}{l}\text { Financial } \\
\text { flows }\end{array}$ & $\begin{array}{l}\text { Requires financial institutions to submit cash flow projections for } 2004 \\
\text { following central bank guidelines. }\end{array}$ \\
\hline $\begin{array}{l}\text { Nov } 14,2003 \\
\text { (Circular 1.882) }\end{array}$ & $\begin{array}{l}\text { Prudential } \\
\text { limits }\end{array}$ & $\begin{array}{l}\text { Modifies the definition of net open foreign exchange position to } \\
\text { incorporate forward positions. }\end{array}$ \\
\hline $\begin{array}{l}\text { Feb 28, } 2004 \\
(\text { Circular 1.901) }\end{array}$ & Audit & $\begin{array}{l}\text { Requires financial institutions to set up a unit for internal audit and an } \\
\text { audit committee including a minimum of two board members. The audit } \\
\text { committee is to issue an report at least every six months. This regulation } \\
\text { already existed but certain key concepts were clarified. }\end{array}$ \\
\hline $\begin{array}{l}\text { Mar 3, } 2004 \\
\text { (Circular 1.905) }\end{array}$ & $\begin{array}{l}\text { Prudential } \\
\text { limits }\end{array}$ & $\begin{array}{l}\text { Establishes limits to the exposures with foreign governments, being } \\
\text { positive for those with risk rating equal or higher to AA-. }\end{array}$ \\
\hline $\begin{array}{l}\text { Jun } 3,2004 \\
\text { (Comunicación } \\
2004 / 146)\end{array}$ & $\begin{array}{l}\text { Credit } \\
\text { classification }\end{array}$ & Establishes credit classification guidelines for securitized credits. \\
\hline $\begin{array}{l}\text { Aug 6, } 2004 \\
\text { (Comunicación } \\
\text { 2004/205) }\end{array}$ & $\begin{array}{l}\text { Consolidated } \\
\text { supervision }\end{array}$ & $\begin{array}{l}\text { Creates a database with information of the economic groups, that include } \\
\text { local and foreign entities of the financial and nonfinancial sector, } \\
\text { connected to individuals or enterprises subject to BCU supervision. }\end{array}$ \\
\hline $\begin{array}{l}\text { Dec } 9,2004 \\
\text { (Comunicación } \\
\text { 2004/352) }\end{array}$ & $\begin{array}{l}\text { Financial } \\
\text { flows }\end{array}$ & $\begin{array}{l}\text { Requires financial institutions to submit cash flow projections for } 2005 \\
\text { following central bank guidelines. }\end{array}$ \\
\hline $\begin{array}{l}\text { Dec } 10,2004 \\
\text { (Comunicación } \\
\text { 2004/356) }\end{array}$ & Credit bureau & $\begin{array}{l}\text { Expands the coverage of the credit bureau by requiring banks to submit } \\
\text { information of borrowers with outstanding debt with the bank exceeding } \\
0.025 \text { percent of the basic capital requirements (down from } 0.15 \text { percent). }\end{array}$ \\
\hline $\begin{array}{l}\text { Jan } 18,2005 \\
\text { (Comunicación } \\
\text { 2005/019) }\end{array}$ & $\begin{array}{l}\text { Credit } \\
\text { classification }\end{array}$ & $\begin{array}{l}\text { Effective January 2006. Increases the number of credit risk categories } \\
\text { from } 5 \text { to } 8 \text { to expand the array of provisioning for credit risk. More } \\
\text { emphasis is given on capacity to repay and analysis of risk factors } \\
\text { affecting the debtor. For nonresident financial institution borrowers the } \\
\text { classification is based on reputable international rating institutions. For } \\
\text { domestic financial institutions, classification is based on actual payment } \\
\text { history. }\end{array}$ \\
\hline $\begin{array}{l}\text { May 13, } 2005 \\
\text { (Circular 1.933) }\end{array}$ & $\begin{array}{l}\text { State bank } \\
\text { regulation }\end{array}$ & $\begin{array}{l}\text { Regulates the sanctions that the BCU can impose on financial institutions, } \\
\text { explicitly including state banks and their senior management. }\end{array}$ \\
\hline $\begin{array}{l}\text { Aug 30, } 2005 \\
\text { (Circular 1.938) }\end{array}$ & $\begin{array}{l}\text { Capital } \\
\text { requirements }\end{array}$ & $\begin{array}{l}\text { New capital requirements effective June } 2006 \text {. Establishes capital } \\
\text { requirements for market risks, higher capital requirements for credit risk of } \\
\text { loans denominated in foreign currency than for those denominated in } \\
\text { pesos. Effective September } 2005 \text {, capital requirements are established in } \\
\text { units indexed to the CPI. }\end{array}$ \\
\hline $\begin{array}{l}\text { Dec 14, } 2005 \\
\text { (Comunicación } \\
2005 / 265 \text { ) }\end{array}$ & $\begin{array}{l}\text { Financial } \\
\text { flows }\end{array}$ & $\begin{array}{l}\text { Requires financial institutions to submit cash flow projections for } 2006 \\
\text { following central bank guidelines. }\end{array}$ \\
\hline
\end{tabular}

Source: Superintendency of Banks. 